Max-Planck-Institut für demografische Forschung

Max Planck Institute for Demographic Research

Konrad-Zuse-Strasse 1 - D-18057 Rostock - GERMANY

Tel +49 (0) 3812081 - 0; Fax +49 (0) 3812081 - 202;

http://www.demogr.mpg.de

MPIDR WORKING PAPER WP 2011-021

DECEMBER 2011

\title{
Spatial construction of European \\ family and household systems: \\ a promising path or a blind alley? \\ An Eastern European perspective
}

Mikołaj Szołtysek (szoltysek@demogr.mpg.de)

(C) Copyright is held by the authors.

Working papers of the Max Planck Institute for Demographic Research receive only limited review. Views or opinions expressed in working papers are attributable to the authors and do not necessarily reflect those of the Institute. 


\title{
SPATIAL CONSTRUCTION OF EUROPEAN FAMILY AND HOUSEHOLD SYSTEMS: A PROMISING PATH OR A BLIND ALLEY? AN EASTERN EUROPEAN PERSPECTIVE
}

\author{
MIKOLAJ SZOLTYSEK ${ }^{*}$
}

\begin{abstract}
This essay represents an attempt at a re-examination of the Western scientific evidence for the existence of the divergent "Eastern European family pattern." This evidence is challenged by almost entirely unknown contributions of Eastern European scholars, revealing the stark incompatibility of the two discourses. This paper is informed to a large extent by R. Wall's voluminous research on European household and family systems. Wall's original observation of non-negligible spatial variation within the supposedly homogenous North-Western European marriage and family pattern is used here as a starting point to show the true diversity of familial organization in Eastern Europe, which had been placed at the other end of the spectrum of what was long believed to be a dichotomous division in European family systems. The diversity of family forms and the rhythms of their development in historical Eastern Europe presented in this literature should finally free us from a simplistic view of the continent's familial history, and especially from the perspective implied by the notion of a "dividing line."
\end{abstract}

\section{INTRODUCTION}

The notion that East-Central Europe is the locus of complex family organization and familistic societal values has reached the status of a general dogma in Western social sciences and demography, and has wide currency in other intellectual circles as well ${ }^{1}$. A few scholars have criticized these mainstream perspectives on the topic from an empirical, conceptual, or epistemological point of view, and have suggested the need for moving beyond the stereotypical and artificial divisions of Europe into "Western" and "Eastern." 2 However, as the persistent usage by demographers of the division proposed by J. Hajnal to explain European demographic differentials since the Second World War suggests ${ }^{3}$, the position of the "revisionists" is still largely absent from mainstream discourse. Thus, further attempts to persuade scholars to accept less stereotypical image of families from outside Western Europe are clearly needed. This essay examines once again the existing literature on historical family systems in East-Central Europe. However, it seeks to broaden intellectual horizons by placing the literature side by side with almost entirely unknown contributions of Eastern European scholars, thereby revealing the stark incompatibility of those two discourses. I argue that the

\footnotetext{
* Laboratory of Historical Demography, Max Planck Institute for Demographic Research, Konrad-Zuse-Str. 1, 18057 Rostock - Germany. Email to: Szoltysek@ demogr.mpg.de.
} 
Western homogenizing view of Eastern European family patterns stems equally from three specific attitudes: 1) the drawing of bold inferences from partial and inconclusive evidence, 2) the neglect of the substantial counterfactual testimony, and 3) the failure to consider the local, "native" Eastern European literature on family and demography.

This paper is organized into four major sections. It opens with a re-examination of the evidence for the existence of a divergent "Eastern European family pattern," followed by a review of the most vivid manifestations of this concept in contemporary scholarly literature. Next, well-established—albeit thoroughly ignored-evidence from Western mainstream demography and family history will be revived and compared with the dominant discourse. In the third and most extensive section, selected contributions of Eastern European scholars will be presented to reveal concepts of familial developments which came into being independently of the Western search for sharp contrasts in familial characteristics on the European continent. The paper closes with a general discussion and conclusion ${ }^{4}$.

\section{THE 'GREAT EUROPEAN DIVIDE’: THE WESTERN PERSPECTIVE}

One of the central tenets of sociological and historical studies of the family has long been the existence of a specific, peculiar "Eastern European type" of family system. A century after the concept of "Eastern European" geographic space emerged among enlightened intellectual elites in the West ${ }^{5}$, the idea that family developments in Eastern Europe diverged from those in the West frequently articulated in 19th-century ethnographies. The German Romantic August v. Haxthausen wrote extensively about the Slavic agrarian constitution and rural organization, and argued that the Russian peasantry were invariably organized in large, extended, and patriarchally structured families ${ }^{6}$.

However, Eastern European "specificity" was first captured and, consequently, juxtaposed with the patterns that are assumed to dominate the West in the works of F. Le Play

${ }^{7}$. F. Le Play popularized the notion of a gradient of family and household types running from East to West, and claimed that patriarchal, patrilocal, and multi-generational households could be found among "Eastern nomads, Russian peasants, and the Slavs of Central Europe," as well as among the Hungarian population ${ }^{8}$. A review of Le Play's mid-19th household model map ${ }^{9}$ reveals a remarkably regular distribution of different family types across the countries of Europe, with clear divisions between the Eastern regions of the continent on the one hand, and the Northern and Western regions on the other. The line he drew on his map between those three large macro-regions, which ran approximately from St. Petersburg to Triest and 
then down the Appenin Peninsula, marked the boundary between the patriarchal families of the East and the stem and unstable families of the West and North ${ }^{10}$.

Le Play's conclusions about family structures in Eastern Europe were, however, derived from a study of only seven families who were largely concentrated in two highly dispersed regions, from the Urals to Hungary and Slovakia ${ }^{11}$. Le Play's approach, although innovative and valuable in many respects, could hardly fit the requirements of modern social science methodology, especially when it came to generalizing from single case studies. Despite these obvious shortcomings, many contemporary scholars still hold Le Play's mapping exercise in high esteem ${ }^{12}$. By the second half of the 19 th century, however, a basic image of the Eastern European family system had already been established.

This 19th-century assessment of Eastern European difference sank deep into the collective consciousness, and was later perpetuated in modern historical demography and family history, despite the discipline's otherwise strong revisionist drive regarding other aspects of older scholarship ${ }^{13}$. The myth of the existence of a demographically uniform Eastern Europe, where people marry young and live in patriarchal households, was presented most enduringly and pervasively in J. Hajnal's 1965 article on marriage patterns in Europe ${ }^{14}$. Hajnal summarized his theses, developed on the basis of an analysis of aggregate statistics from around $1900^{15}$, in a very concise statement: "The marriage pattern of most of Europe as it existed for at least two centuries up to 1940 was, so far as we can tell, unique or almost unique in the world. There is no known example of a population of non-European civilization which has had a similar pattern." 16 The "European pattern," the distinctive features of which Hajnal considered to be a high age at marriage and a high proportion of people who never marry at all, pervaded, according to him, "the whole of Europe except for the eastern and south-eastern portion." (ibid.) ${ }^{17}$ Reiterating Le Play's original spatial exercises, Hajnal introduced an East-West gradient in European demographic behaviors with much greater force, and argued that "the European pattern extended over all of Europe to the west of a line running roughly from Leningrad (as it is now called) to Trieste."18 Hajnal significantly hardened Le Play's initial distinctions between Eastern Europe and the rest of the continent, and was keen to equate the marriage pattern of several countries located "east of the line" with marriage characteristics of "non-European civilizations." ${ }^{, 19}$ In his 1965 article, Hajnal also linked the European pattern of late marriage with the stem family as defined some hundred years before by Le Play, but he seemed to treat it as more akin to simple rather than joint (patriarchal) family systems. Hajnal's text can also be read as strongly suggesting the 
incompatibility of early marriage behavior (ascribed to Eastern Europe) with simple or stem family systems believed to prevail in other parts of the continent.

In the meantime, P. Laslett elaborated on, reiterated, and retold Hajnal's original hypotheses. Laslett started with envisaging the specificity of the English nuptiality pattern by indicating that marriage in the English context meant the creation of a new economic unit ${ }^{20}$. Soon after, however, he took the specificity of English marriage and household behavior to be representative for Western Europe as a whole, and, at the same time, he described it as a characteristic which had probably distinguished "the west and the north of Europe from the east and the south." ${ }^{21}$ In Household and family in past time, what illuminated the Western familial pattern ("West" meaning mainly Western Europe and America) were the starkly conflicted marriage and household patterns observed in "Far Eastern Europe" (rural and urban Serbia) and in Japan ${ }^{22}$. Laslett's perspective on pre-industrial Eastern Europe as representing the greatest intra-European departure from the "English standard," and from Western Europe as a whole, can be easily discerned from his various, but geographically non-systematic, accounts in the volume ${ }^{23}$.

Laslett's view of intra-European differences in family systems were crystallized in his 1977 paper $^{24}$. Despite seeing the geography of European family systems as "being complex and puzzling," 25 and acknowledging the limited availability of data for continental Europe, Laslett was not discouraged from making bold interpretative inferences from single case studies. He outlined several features of North-Western European households in the Early Modern era, subsuming them under the label of "the Western family pattern." He then considered large parts of what is often referred to as East-Central Europe (Latvia and Estonia in the North, Poland, the Czech lands, northeastern Austria, and also Transdanubian Hungary) ${ }^{26}$ as belonging to a hypothesized "large intermediary area" between Western and non-Western family systems ${ }^{27}$. It was the area with an explicitly "in-between" position (close to the European "core," but still not fully "Western European"), with a cosiderable degree of ambiguity and a tendency towards permutations and possible combinations of marriage and family patterns ${ }^{28}$. A "European Far East" was represented in Laslett's account by Russia (the Baltic states were often included ${ }^{29}$. This concept provided researchers from the Cambridge Group with a long-anticipated place where the complex family was the "universal background to the ordinary lives of ordinary people, ${ }^{, 30}$ and therefore supplied Laslett with the missing element in his mapping exercise.

This now fully articulated notion of the extremes of familial organization within the confines of the European continent was first substantiated by P. Czap's study of a single 
Russian community of Mishino (some 170 kilometers southeast of Moscow; 128 households in 1814 , with a population of 1,173 persons) during the $18^{\text {th }}$ and $19^{\text {th }}$ centuries, the first work in English to make extensive use of the "Cambridge" approach ${ }^{31}$. The outcome of Czap's study posited that there was a specific "eastern European family type" (as opposed to the Western one) which was characterized by a high proportion of three- or more generational multiple-family households, a mean household size significantly greater than five persons, and a more or less general propensity for early marriage within the population ${ }^{32}$.

However, there is a certain level of ambiguity regarding the spatial implications of Czap's "model” case study. Initially, Czap had no reservations about calling marriage behaviors on the Mishino estate "a robust non-European marriage pattern" (without inverted commas), ${ }^{33}$ and he also seemed to be genuinely satisfied with an assertion in a later piece of research that his findings were applicable to large areas of pre-emancipation Russia ${ }^{34}$. Nonetheless, he expressed serious doubts as to whether his "eastern European family type" could have prevailed beyond the ethnic Russian territories of the continental part of the Empire $^{35}$. Better still, he suggested that the southern agrarian provinces were separated in the $18^{\text {th }}$ century from the central industrial region surrounding Moscow by a socio-demographic and familial frontier, although he was unable to define the position of this frontier more precisely $^{36}$. However, in the early 1980s, the search for sharp contrasts in familial characteristics and the wish to brand major areas of Europe as having a particular type of household system were well underway. It was due to this methodological orientation, and also to the general ignorance of Western family historians about Russia and Eastern Europe generally, that Czap's tentative hypothesis suffered the mixed fortune of being regularly assumed to be representative of the whole country, and even of the whole continent to the east of Hajnal's line ${ }^{37}$.

After the publication of this new evidence on the eastern part of the continent, further mapping endeavors were possible. In two papers published in the early 1980s, Hajnal used the concept of the "Western European family" to distinguish between two kinds of household formation system in pre-industrial times: the simple household system in North-Western Europe, and the joint household system (stem family systems in which one of the sons married and took over the farm after his parents retired were considered compatible with the North-Western Europe family system $)^{38}$. By explicitly calling the paper he published in 1982/1983 a "sequel" to his famous 1965 essay, Hajnal seemed to suggest that the two supranational, large-scale family systems he was studying could be spatially conceptualized as referring to territories west and east of his famous line. However, Hajnal's geographic 
references were flawed and imprecise. Since in 1983 there was no substantial body of evidence available to him for studying European east-of-the-line territories, he made no explicit commitment about the kind of household system that was characteristic of Eastern Europe in the past. Nevertheless, he was oblivious to Czap's reservations regarding the interpretation of the Russian data, and used his Mishino case study as if it were representative of all of the European East, or at least of all Eastern European serf populations in pre-modern times $^{39}$. Similarly, he disregarded Laslett's remarks cautioning that there was a striking variegation of East-Central territories when he jumped thousands of kilometers south-west from Mishino to use circumstantial data from Hungary and Croatia to supplement his case for the prevalence of joint family systems in other Eastern European regions ${ }^{40}$.

By contrast, Laslett refined Hajnal's argument and departed from a simple dichotomous East-West model of European familial differences, arguing instead for two additional sets of tendencies, which he saw as bridging the most extreme contrasts in domestic group organization on the continent. For this ambitious mapping exercise, Laslett used a household composition dataset that was very limited, even compared to the data used in his earlier speculative essay from 1977, and treated data from several single location points as illustrative of regions of Europe which seem to have had distinguishable forms of family and household (these "domestic group tendencies" were West, West/Central or middle, Eastern, and Mediterranean $)^{41}$. Laslett took the "eastern tendencies" illustrated with the Mishino data as "justifiably associated with the domestic group structure of European Russia as a whole [sic!] and some of its surrounding areas." ${ }^{42}$ On the other hand, his notion of "West/Central or middle" tendencies was accompanied by strong geographical and definitional uncertainties. He asserted that the area in which such tendencies have been found lacked a clearly marked pattern, and he therefore proposed treating those domestic group constituencies as an intermediate category, though closer to that of the West than to the Mediterranean or Eastern categories ${ }^{43}$. Laslett's "sets of tendencies" in the middle zone complied geographically with the claims of Central Europeanists of the 1980s, and therefore included "small nations between Germany and Russia." 44 Large parts of historical Poland-especially the Belarusian, Lithuanian, and Ukrainian territories-would probably be allocated within the zone of the alien, "Eastern" familial tendencies ${ }^{45}$. Strikingly, in this influential paper positing a "four region hypothesis" in domestic group organization, only two locations were mentioned from the vast area stretched along the West-East axis from Oldenburg and Vienna in Germanspeaking countries, to the Ryazan province south of Moscow in the east (two Hungarian 
settlements). This immense space "in-between" was a "terra incognita" in European family systems.

Laslett's and Hajnal's tentative generalizations have long been held in esteem. This reverence, as well as the prolonged scarcity of research material available for Eastern Europe, encouraged other scholars to indulge in intellectual equilibristic and bold generalizations. Wrigley from the Cambridge Group argued that in Eastern Europe, "huge and complex households predominated with extensions both laterally and vertically," presenting "a dramatic contrast" with Western European standards. For "Middle Europe," however, Wrigley envisioned less uniformity and a wider prevalence of family forms intermediate in size and complexity ${ }^{46}$. French historical demographers would not admit to having any doubts that "[f]rom Serbia in the south to Courland or Estonie in the north, passing through Poland and Russia, one encounters certain common features: a household size which is much larger than in the West, and a strong propensity for multiple households." ${ }^{47}$ Reflecting upon several decades of research, Plakans recently remarked that the propositions about the historical characteristics of Eastern European family life; namely that "low ages at first marriage, low proportions not marrying, high proportions of complex households (...) - have retained a great deal of validity, and can therefore serve as a set of baseline characteristics for exploring the rest of the nineteenth century." 48

Laslett's and Hajnal's hypothetical generalizations provided a ready and badly needed framework for scholars from other fields wishing to understand recent family, or even sociopolitical, developments. Within this framework, the tantalizing claims and tentative inferences of family historians and demographers were eagerly transformed into "solid" scientific evidence that helped to substantiate their own claims. Therborn, for example, referred to Hajnal's nuptiality hypothesis in his global history and sociology of the family to demonstrate that "the classical European family divide, running from Trieste to St Petersburg [...] is still visible in 2000." 49 In a similar spirit, demographers took Hajnal's bipolar division of the continent from around 1900 at face value, and often used it too hastily as an additional tool for explaining European-wide differentials in demographic transformations since the Second World War ${ }^{50}$. Among some anthropologists, as well, Hajnal's notion of the North-West European simple family system continues to serve as an essential framework for explaining the relatively weak kin ties in Northern Europe, as contrasted with the "descent"-oriented and more familistic regimes prevalent in Eastern Europe and the Mediterranean ${ }^{51}$. Many recent demographic studies of contemporary European household structures still take Hajnal's and 
Laslett's mapping exercises for granted and use them as a reference point for the comparison of patterns observed in nowadays Eastern Europe ${ }^{52}$.

\section{DISSIDENTS IN THE WEST: THE RECONCEPTUALIZATION OF THE WESTERN AND THE EASTERN EUROPEAN FAMILY}

All this was taking place-irrespective of the growing criticism in the West of the accuracy of Laslett's and Hajnal's accounts of regional variation in European household forms during the 1990s_largely because of Richard Wall's voluminous research. Richard's first piece, in which the topic of intra- and inter-regional variation in familial organization was first tackled, was a relatively unknown study from the $1970 \mathrm{~s}^{53}$. It opened by describing Laslett's vision of a typical English household-i.e., small, containing surprisingly few children and kin but large numbers of servants - as turning "into something approaching a stereotype, more particularly in regard to mean household size, to be applied to all manner of English communities regardless of location or time period." Wall then made an attempt to propose a "correction [to that picture] by charting variations in household size and structure between the seventeenth and nineteenth centuries and between one part of the country and another." ${ }^{, 54}$ According to him, not only had demographic rates changed between the pre-1750 and the 1750-1821 periods in England, but, consequently, various aspects of household organization and related phenomena (e.g., the leaving-home process) changed too. The most dramatic modifications of this kind were related to the presence in households of kin and servants, and the number of households headed by females, even though the percentage of three-generational households remained rather low in England (less than 13 percent). Wall also observed that there was a substantial range of variation between individual settlements in England: in some of them, it was possible to find almost no co-resident kin at all, whereas in other groups, they accounted for more than 10 percent of the population. All in all, between 1650 and 1821 the share of households with kin was about 10-13 percent in the selection of English communities, but by 1851 there was a dramatic shift, with the share rising to 20 percent ${ }^{55}$. The changes were not tremendous, but they nevertheless seemed to be too great to be ignored: "Even while it remains relatively robust to the major demographic push of the eighteenth-century, the English household was not static. Nor, given the variations between area and area, would it be correct to see English households as variations on one basic type., 56

The theme was developed further in Wall's paper from 1991, which took advantage of the increased availability of published research and data pertaining to the analysis of household systems in historic Europe. Wall's point of departure was to claim "the illogicality 
of relying solely on the presence or absence of kin as a definition of the household system." This was justified by the fact that the number of persons of all types found within a household varied considerably in different parts of North-Western Europe (including Spain) ${ }^{57}$. Nevertheless, the figures he provided for the number of relatives (other than spouses and offspring) per 100 households by relationship to household head ${ }^{58}$ already tell us a large part of the story, and are more important here than other methodological considerations. Regional samples from Belgium, Denmark, England, Iceland, the Netherlands, Norway, Spain, and Switzerland revealed figures for relatives per 100 households which varied from five in one Dutch region to the mid- 20s in countries like Belgium and Denmark, to 35 or more in rural districts of Norway and Iceland. In the case of servants, the range in variation was even larger. For Wall, these intra-European differences were quite modest when placed alongside the structure of household in some non-European populations. Nevertheless, this "considerable variation in household structure even within the confines of northern and central Europe" led him to tentatively discern four household patterns from the pool of available data ${ }^{59}$. The author was convinced that the data he assembled give "a better perspective on what range of variation can be expected within an area which Hajnal's North-west European household system is supposed to dominate." He added, quite stunningly, that "so great is the degree of variation that it must be doubtful whether Hajnal's generalization captures much of the reality of family and household patterns of north-west European societies in the past." [sic! $]^{60}$

The theme of variation, divergences, and similarities in European family systems resurfaced rather forcefully in two papers published by Wall in the late 1990s and early $2000 \mathrm{~s}^{61}$, both of which investigated the accuracy of Laslett's and Hajnal's accounts of regional variation in European household forms. Using the sample of English populations from the 1851 census, Wall showed that up to one-fifth of households in some of these populations were complex (by complex, he meant a cumulative percentage of extended and multiple families). He therefore raised serious doubts about whether it is justified to claim that the proportions of complex households were indeed "very low" in England, as Laslett did on many occasions. While Richard did not reject entirely the notion of English specificity, he perceived it differently from his predecessors. "What is (...) most distinctive about the English experience," he noticed, "is its uniformity, relative to the variation in household forms occurring in other parts of Europe." France, Spain, and Italy had regions dominated by simple family households, but, equally, they had populations with proportions of multiple family households far in excess of the shares seen in any of the English communities. According to Wall, the latter feature was also a prime characteristic of Eastern Europe. Yet 
even there the occurrence of multiple families might have occasionally resembled rates observed in other parts of Europe, in Italy in particular ${ }^{62}$. Not only could many distinctive patterns be identified within the confines of pre-industrial North-Western Europe, Wall asserted, but the pace and timing of familial change in the different parts of the continent likely varied considerably ${ }^{63}$.

If the supposed foundations of the North-Western European familial specificity were substantially shattered by the research of people like Wall, the emerging orthodoxy proclaiming the East-West familial dichotomy was on even shakier ground. This "demographic brotherhood of thought" regarding the familial characteristics of the eastern part of the continent has actually turned out to be a smokescreen that hides substantial differences in research perspectives.

Among of the earliest heterodox investigations into Eastern European household structures were Plakans' studies of the big Latvian parish of Nerft in $18^{\text {th }}$-century Kurland (17 noble estates, 771 farmsteads, 11,040 individuals) ${ }^{64}$. An intriguing outcome of this careful examination of surviving household lists was the observation that, despite being representative of the family pattern that contrasted sharply with what was known for the West, the complex family in Latvia was not a universal feature in the lives of ordinary people ${ }^{65}$. Plakans' remarks went largely unnoticed by Cambridge scholars.

In the meantime, Sklar carefully collected census-type evidence for every political entity of the Eastern European region from around 1900, which she then minutely decomposed into smaller political units ${ }^{66}$. Following Hajnal in this matter, Sklar summarized her analysis in a very concise statement: “(...) the East European regions that were to become Latvia, Lithuania, Estonia, Czechoslovakia, and Poland after World War I did not exhibit the Eastern European pattern of marriage behaviours, but were actually closer to the West European pattern." By referring to values of the singulate mean age at marriage, she argued that "nuptiality in these regions at around 1900 followed the West European late marriage pattern," with the mean age at first marriage fluctuating between 24 and 27 for women, and between 25 and 30 for men. Sklar observed commonalities across Estonia, Latvia, Lithuania, Poland, and Czechoslovakia in the proportions single at different age groups, with only a slight departure from this general tendency found over territories that were later to become Poland. She concluded that persons in all these areas "married rather late, and moderate proportions never married at all." ${ }^{, 67}$ In light of this abundant evidence, Sklar felt at ease in concluding that, in Eastern Europe around 1900, both "Western" and "Eastern European" 
marriage patterns prevailed, with the latter being followed by the Balkan countries. She substantiated her claims by using basic data to show that, around 1900, there were only negligible differences between household sizes in the Baltic, Czech, and the Polish provinces and household size in Sweden (with the mean household size fluctuating between 4.7 and 5.2 persons); but that there were more significant differences in relation to Bulgaria and Serbia (which had mean household sizes of 5.8 and 7.2, respectively). More speculative, but still very interesting in the context of the discussion of Hajnal-Laslett models, were Sklar's comments about the relationship between marriage and residence patterns, and the way they both were buttressed through kinship rules and practices in various parts of Eastern Europe. On the basis of "historical and observational studies" Sklar maintained that "in the Czech, Baltic and Polish territories, the independence of nuclear family was reflected in the custom that the typical peasant farm should support one family only (...)," and that the peasant practice was "to leave a farm undivided to one son who would marry and remain on the holding while 'paying-off' his brothers and sisters (...)." Both of these observations vividly recalled Hajnal's own description of Western European stem family societies. According to Sklar, the emphasis upon the independence of the nuclear family in the Czech, Baltic, and Polish provinces produced strong pressures that tended to favor late marriage, sometimes leading to celibacy among the non-inheriting offspring. In contrast, the integration of the nuclear unit into the parental household in the Balkans created pressures favoring early marriage ${ }^{68}$.

Sklar's observations were close to Hajnal's own description of marriage as being contingent on the availability of self-sufficient positions or niches, and on the inheritance practices he saw as underlying the formation of typically North-Western European households. Unsurprisingly, Sklar seemed fond of relocating the dividing line suggested by Hajnal more towards the east, so as to include the countries such as Latvia, Lithuania, Estonia, Poland, and Czechoslovakia into the zone of "Western" marriage and household characteristics. Her repositioning of the demographic fault line in Eastern Europe suggests that parts of the Lithuanian, Belarusian, and Ukrainian ethnic territories of the Polish state may have been included in the "Western" zone ${ }^{69}$. By suggesting there were at least two distinct marriage patterns in the region, Sklar's paper refuted notions of historical Eastern Europe as a demographic monolith for the first time in modern population history. Her study found not only a transition zone along the North-South axis, which seemed to delineate EastCentral European from Balkan marriage patterns, but it also revealed noteworthy differences within East-Central Europe itself. Finally, Sklar's analysis opened up options for recasting 
Eastern European marriage and family patterns at the turn of the $19^{\text {th }}$ century, but only a few researchers took advantage of the opportunity presented ${ }^{70}$.

Chojnacka, a student of A. Coale at Princeton, proceeded along similar lines, and found a true spatial diversity of marriage behaviors in Tsarist Russia around 1900. Three belts of marriage regimes stretching from the west to east displayed a gradual decrease in nuptiality when moving from the south to the north of the country. Chojnacka confirmed Sklar's earlier observation, and suggested a correction to Hajnal's hypothesis: "[A]pplying Hajnal's terminology, the non-European pattern - defined as early and quasi-universal marriage - can be applied in the south and central regions of European Russia, but not in the north. The latter is much closer to the unique European marriage pattern." ${ }^{\text {71 }}$ Although Chojnacka was not able to establish a clear relationship between different patterns of marriage and different types of families, she nevertheless tentatively suggested that "an extended patriarchal-type family" was dominant "among the Great Russians, with a variety of modifications among the White Russians, and to a lesser extent among the Ukrainians." Among the latter, she claimed, "the nuclear family was more common." 72 As we can see, no claim for the universality of the prevailing family type on Russia's western fringes was made here.

Hajnal's hypotheses were also partly questioned by the authors of the Princeton monograph on Russia ${ }^{73}$. Their collection of figures on the singulate mean age at first marriage and the proportion ever married for Western European, Eastern European (including European Russia), and non-European (Asian and African) societies provides grounds for challenging Hajnal's attempt at equating the "Eastern European pattern" with the marriage characteristics of "non-European civilizations" as misleading. In both indexes, the contrast between "Western" and "Eastern" European populations (the latter being Bulgaria, Hungary, Romania, and Serbia; as well as Ukraine, Belarus, Lithuania, Latvia, and Estonia) was reminiscent of distinctions between the latter group and non-European populations from the Far East and North Africa ${ }^{74}$. Moreover, there was by no means an unequivocal spatial order to marriage and family patterns even to the east of Hajnal line. Again, three distinct patterns of first marriage were detected within European Russia, with the Baltic republics sharing the late experience of first marriage long customary in Western Europe ( $I_{m}$ of 0.56 or less in 1897), and Belarusian and Ukrainian territories displaying an "intermediary pattern" ( $\mathrm{I}_{m}$ of 0.62 to 0.68) between the above and the pattern of early marriages characteristic of territories stretching almost horizontally from the Black Sea to the Urals. The examination of spatial distribution of SMAM values for Russia's westernmost provinces in 1897 indeed revealed 
quite substantial differences in marriage ages, which, however, did not unfold along a WestEast axis, but rather vertically ${ }^{75}$.

A similar perspective was advocated in J. Ehmer's study of historical marriage patterns in the crown lands of the Austro-Hungarian monarchy, 1880-1890 ${ }^{76}$. Ehmer pinpointed a striking divergence of the Galician nuptiality regime from trends common among populations of the Kingdom's other provinces ${ }^{77}$. In Galicia at the end of the $19^{\text {th }}$ century, he suggested, the age at marriage tended to be much lower: in some regions almost all men were married by the age of 30 , and permanent celibacy was nearly unknown ${ }^{78}$. When entering East Galicia, Ehmer observed, "we are leaving behind the European Marriage Pattern and Household Formation System." However, even though he treated this area as a demographic monolith, Ehmer suggested there was a demographic fault line running across the province which divided it into two parts along ethnic lines. The western part, with the great majority of Poles (up to 90 percent of the local population) was characterized by relatively large proportions of never-married males, whereas the situation differed greatly in districts dominated by the Ruthenian (Ukrainian) population. Importantly, in Ehmer's view the eastern Ukrainian family pattern represented an example of the East-Central European family type, which was supposed to prevail over the entire Carpathian area and extend into the eastern Ukraine as well. It was distinguished by the pattern of earlier marriage that "might really be a transitional form towards Eastern European Marriage Pattern," and also by patrilocal household formation and a strong tradition of complex, patriarchally structured family forms, but by a relatively small household size. Ehmer concluded that the marriage patterns of the Polish-speaking population in western Galicia departed only slightly from the more Western-like tendencies of the other crown lands of Austro-Hungary ${ }^{79}$. Ehmer's contribution supplied yet more proof of the need to variegate the view of family tendencies east of Hajnal's dividing line. Still, Ehmer's picture of variety in East-Central Europe was painted with a broad brush, and the concept of a transitional zone between Western and Eastern marriage and household patterns located somewhere in East-Central Europe, to which he subscribed, needed to be fleshed out with a more substantial body of evidence.

The concept of a transitional zone between Western and Eastern marriage and household patterns was later fuelled by another Austrian scholar. In two publications, M. Cerman pointed out that Early Modern Central Europe may be thought of as representing the transitional area with respect to the European marriage pattern and different household formation systems. By focusing on Austrian and Bohemian data from the $17^{\text {th }}$ and $18^{\text {th }}$ centuries, Cerman blurred the existing geography of marriage patterns in that part of Europe 
by asserting that there were surprisingly high proportions of married males in Bohemia relative to Austrian areas as early as in the $17^{\text {th }}$ century, and by suggesting that there was an additional North-South fault line in the region ${ }^{80}$. However, he still argued that in the Early Modern period Austria shared the same more "Western-like" household and family formation system with Bohemia, but not with Slovakia, where higher proportions of complex households were found together with a lower mean age at marriage. Cerman was reluctant to see Slovakian family pattern as representing an "Eastern Hajnal-type family system;" instead, he claimed it was far more appropriate to view Slovakia as being part of a "very broad transitional zone, whose dominant household patterns were strongly influenced by local and regional socioeconomic and legal contexts." In Central Europe, he continued, "there existed not only an extreme variant of the Western European pattern (...) in rural areas of Austria, but also significant variations from this Western European pattern in other regions such as Slovakia and Hungary (...). The famous Hajnal line which appears prominently in the literature in its role as structural border between Eastern and Western family systems appears therefore to be diffused by the presence of areas where family forms were more mixed." ${ }^{21}$

Since the early 1980s, attempts have also been made at canvassing the Balkan family and demographic realities ${ }^{82}$. Although Todorova was very cautious in inferring generalized claims from the micro-censuses she examined for the 19th-century Bulgaria, she nevertheless asserted that the Balkan region should not be incorporated as a whole into the non-European or Eastern European marriage and family patterns. Although her analysis of data from both rural and urban areas of Bulgaria generally confirmed the contrast made by Hajnal between Western and Eastern European patterns of female marriage, it also confirmed the assumption that there was relative uniformity in Western Europe and the Balkans regarding the average size of the household and the distribution of the households by composition. "The characteristics of the family and the household [in northeastern Bulgaria of 1860s]," Todorova concluded, "do not make possible the establishment of some essential difference from the West European model. ${ }^{\prime 83}$ As in many places outside of Eastern and South-Eastern Europe, Bulgarian family pattern was characterized by the predominance of simple-family households (some 60-70 percent of all domestic units), alongside a substantial proportion of extendedfamily and multiple-family households (12-16 percent of the latter), with, however, an allowance for individual cases in which the pattern was leaning significantly towards the Eastern type. Accordingly, Todorova re-conceptualizes the South- Eastern European area as having a great deal in common with Central and Southern Europe, particularly with regard to the occurrence of multiple families ${ }^{84}$. 
Recently, S. Gruber used micro-census data from Serbia and Albania to extract information on historical household formation and marriage patterns in both countries, and found some interesting inter-country differences behind the general structural similarity of family patterns. The male age at marriage was higher in Albania, and Albanian men were married over a longer periods of their lives than the Serbs. There were similar proportions of multiple-family households in rural areas in both countries, but they contained many more cousins in Albania than in Serbia. Almost all of the Serbian households were divided in each generation, while Albanian households were divided less frequently. Albanian cities clearly had higher percentages of multiple family households than Serbian urban locations. The proportions of unmarried people were quite similar, as was the average household size in both countries. Gruber's conclusion was that there are more indicators for different patterns than for only one family pattern in the two Balkan regions ${ }^{85}$. When confronted with the diversity of family arrangements stemming from an increasing number of micro-structural studies of Balkan communities, other scholars have rejected the very notion of typical Balkan household arrangements ${ }^{86}$.

\section{SPEAKING FOR ITSELF: EASTERN EUROPEAN STUDIES ON FAMILY AND}

\section{MARRIAGE}

Although the first independent studies on Eastern European household structures appeared at almost exactly the same time as when the Cambridge Group framework for comparative analysis of families was completed and was made known to a wider research community ${ }^{87}$, their sensible voices went largely unheard by Western scholars. Either they were mentioned only in passing, without affecting the general picture usually drawn, or they became known to a wider public too late to halt an ongoing stereotyping of Eastern European demographic realities ${ }^{88}$. These studies were, however also preceded by even more voluminous literature from the period between the mid- $19^{\text {th }}$ century and the early 1960 s which anticipated many threads of contemporary English, Austrian, or French studies on the history of family and kinship, even though they worked on different methodological premises and had different research goals. In this section, I will first briefly review these older perspectives on familial issues, and will then look at more contemporary literature.

\subsection{9th- and early 20th-century contributions}

Among the objects of heated debates among Eastern European scholars since the late $19^{\text {th }}$ century has been the issue of "intra-familial relationships" (a term used to describe the totality 
of issues pertaining to familial land ownership, inheritance, kinship, co-residence, and, to a degree, residential propinquity of relatives). In practice, the points of disagreement have been related to the origins, size, legal character, and spatial distribution throughout Eastern Europe of the so-called zadruga-type family forms; that is, a family community that in modern studies is frequently categorized as belonging to the residential community group ${ }^{89}$. Following Bogišić, nearly all of the Southern-Slavic literature has concluded that zadruga is a relic of ancient all-Slavic forms of ancestral organization which can be traced back to the era of first settlement, and several East-Central European authors have also signed on to this theory ${ }^{90}$. This image, popularized in a simplified version in Western literature, would soon sink deep into the collective consciousness; and would, with time, condition the framework of debates on the geography of family forms in Europe ${ }^{91}$ by equating those archaic forms of communal social organization with a supposed propensity to multi-generational co-residence over the whole eastern part of the continent, and among Slavs in particular. However, some of these early scholars also provided a striking acknowledgment of the diversity of family forms in East-Central Europe as early as the late $19^{\text {th }}$ century, and offered particularly perceptive differentiations of various patterns of family forms developing in the western and eastern lands of the historic Polish-Lithuanian Commonwealth.

K. Kadlec assumed that in the medieval times the Central European variant of zadrugal forms known as niedziat (literally, "something undivided") represented a prototypical form of family life common to all Slavic peoples, which was meant to be a commune of people bound by ancestral kinship who jointly manage a shared estate under the guidance of one leader ${ }^{92}$. However, he also pointed out that zadruga-type communes survived for long periods only in southern Slavdom and in Russian countries, while in regions inhabited by western Slavs, they were disappearing more quickly ${ }^{93}$. Among Poles, they disappeared earlier than among Czechs, most likely before the end of the $16^{\text {th }}$ century. The disintegration of niedziat progressed along different patterns among Czech and Slovak populations, as well. Among the rural Czech population, it was only occasionally found in the $18^{\text {th }}$ century, while in Slovakian territories (especially around the Carpathians) its remnants were detected a century later. The more rapid process of the individualization of family life and property laws in western Slavdom was caused mainly by the influence of Western concepts, especially the terminology of German law, and was manifested in the simpler structures and smaller sizes of local "undivided family communes" relative to the structures found in Russian lands, and especially in the Balkans ${ }^{94}$. In Poland, as in the Czech territories, family collectives were rapidly reduced to forms of tighter communes embracing the joint 
familial property in a narrow sense of the term, most frequently between the father and his unmarried sons ${ }^{95}$.

The crowning jewel of Polish discussions of zadruga-type family forms were the works of Balzer and Łowmiański. Balzer found big family communes in medieval Bohemia, in Poland proper, as well as in the Polish eastern borderlands, where they assumed forms identical with patterns known from Southern Slavdom or Ancient Rus. However, these zadrugal forms in Eastern Europe varied in durability. They disappeared fastest from the territories of the Polish Crown and Bohemia, and, if they lasted longer, then usually as relatively simple and small two-generational communes ${ }^{96}$. On the western fringes of Ukraine, family communes lasted well into the $16^{\text {th }}$ century, both among the gentry and the peasant population. In some minor regions they did in fact survive up until the $18^{\text {th }}$ century, but then only among peasants. Eastern European family communes differed also with regards to their life-cycle characteristics. In Poland and Bohemia, they took the form of temporary joint property groups (sometimes, but not always, also co-resident entities), which usually split either immediately or shortly after the demise of the head. Further to the east of Poland, undivided family units were more durable: out there, communes among brothers lasted over their entire lives ${ }^{97}$.

Łowmiański was the first to reinterpret communal property systems on LithuanianRuthenian lands of $16^{\text {th }}$-century Poland in strictly demographic categories. Importantly, according to Łowmiański, the property communes jointly managing the land were composed of separate households, or dyms (hearths). The number of dyms making up a commune could vary substantially, and in Lithuanian regions was lower than in Volhynia and Polessie (northern Ukraine). Furthermore, dyms also differed considerably in size: in the southern belt of the Lithuanian-Ruthenian lands, they were bigger than in the more northern regions of the Grand Duchy ${ }^{98}$.

Those discrepancies were but a signal of much more substantial differences in the material and social culture of the Slavic people since the earliest medieval times ${ }^{99}$. Among Slavs the disintegration of lineage groups into small families had already occurred during the period of intense settlement between the 7th and 10th centuries; however, this process did not result in the conjugal family gaining primacy everywhere ${ }^{100}$. At least in 16 th- to $18^{\text {th }}$-century Poland, grand families of the scale of extended Balkan zadrugas did not occur, allowing only for the occasional occurrence of households of more than one married couple ${ }^{101}$. However, in some regions of Slavdom, the strong lineage system survived until very recent times ${ }^{102}$. Small and nuclear families from the $18^{\text {th }}$-century Polish Crown could be juxtaposed with residential 
communes from Belarus, where at that time there was a greater share of multiple households than of single households (even up to 60 percent), as the population avoided a general parcelling of households and extensively used familial property communes ${ }^{103}$. According to Łowmiański, the grand Belarusian families from the late Early Modern period were the continuation of a previously vanished institution prevalent in the western lands of the Polish country.

\subsection{Czech, Slovak, and Hungarian literature}

These early suggestions regarding the presence of an East-West gradient in family composition in Eastern Europe provided a unique agenda for more quantitatively elaborated studies on the structure of the family. Unfortunately, contemporary Eastern European family historians sought to develop these earlier insights only to a very limited extent.

They resurfaced most extensively in the Czech and Slovak literature. The investigation into family and household structures in the former Czechoslovakia dates back to the late 1980s, when "The 1651 Register of Subjects According to Their Religion" (Soupis poddaných podle víry), covering almost all of the lands of historical Bohemia, was first examined with the use of quantitative techniques ${ }^{104}$. Since then, one of the basic premises of Czech and Slovak scholars studying historical household structures has been that there may be an intermediary marriage and household formation pattern in Central Europe ${ }^{105}$. Horska was the first to introduce the concept of "Central European model of the family" ${ }^{106}$, by which she meant a nuptiality pattern that was transitional between the North-Western and Eastern European models. She also asserted that, during $17^{\text {th }}-19^{\text {th }}$ centuries, the family household in the Czech countries never seems to have been of the patriarchal, 'zadruga-like' type: it was most frequently composed of the parents and children, as "elsewhere in Western Europe."107 Several studies confirmed the overwhelming dominance of nuclear households in $16^{\text {th }}$ and $17^{\text {th }}$ century Bohemia (up to $79 \%$ ), followed by extended households (up to $32 \%$ ), but only a very small share of domestic units shared by more than one family (up to 9\%). In addition, a significant fraction of the young unmarried population in Bohemia was found to have worked as unmarried servants in the households of non- $\operatorname{kin}^{108}$. All of these features made it possible to treat the Bohemian variant of the Central European pattern of the family as being more or less compatible with patterns observed in Western Europe.

At the same time, however, Horska and others warned that an important demographic fault line passed through Czech lands during the Early Modern period. Whereas in Bohemia more complex family types may have been widespread only before the $17^{\text {th }}$ century, the "great 
family" was much more usual in the Moravian Carpathians and Slovakia, where it frequently involved the co-residence of married brothers and sisters in a manner resembling the jointproperty systems of a fraternal zadruga type ${ }^{109}$. A feature that differentiated such residential arrangements from the Eastern or South-Eastern European realities was, however, specific power relations within households, whereby a co-residing brother could occupy an inferior position and was entitled to have a share in the household consumption only if he performed various labor services for the brother-head. The non-negligible geographical pattern was also believed to have existed in the Czech lands with regards to nuptiality, as the age at first marriage declined as we proceed from the northwestern to the southeastern parts of the region $^{110}$. Švecová drew on ethnographic literature to link these two different family and demographic regimes in the area of the former Czechoslovakia with two types of property devolution: the one-heir system known as "rodina jednonástupnická," and joint property systems known as "rodina nedielová." 111 She also proposed that there was a decisive turn along the way from the Eastern type of household formation (rodina nedílová) to the Central European pattern (one-heir system), which could be found in Bohemian lands between the late $16^{\text {th }}$ and early $17^{\text {th }}$ centuries, but not in Slovakia ${ }^{112}$. In the latter, the development of nuclear- or stem-family arrangements was prevented by the family joint-property system, equal inheritance among sons, the real partition, and, finally, by the strictly agrarian environment (Švecová 1966, 85; 1986, 204; 1996, 15-16; also Langer, 1994, 44). Instead, three- or four-generation families with partilocal marriage and patriarchal power relations were quite prevalent; a the pattern which often persisted well into the $20^{\text {th }}$ century ${ }^{113}$. Švecová was persuaded to consider the Slovakian family pattern as belonging to the "Eastern" type of Hajnal's typology, with the Western Carpathians representing within the Central European setting the border between two different family models suggested by himself ${ }^{114}$.

A similar variegation of family patterns was also found for late 18th- and early 19thcentury Hungary. Andorka refuted the notion that poly-nuclear households would have represented something of a general pattern in Hungary. Although they were fairly widespread in the Transdanubian region, places where the share of nuclear households was much greater and extended and multiple families were much less prevalent could be easily found in other areas of the country ${ }^{115}$. A later study of seven localities from the period between 1747 and 1816 suggested that the household structure in Hungary "seems to have been intermediate between western Europe on the one hand and Serbia and Russia on the other," but with allowances that important differences may have existed within the country itself ${ }^{116}$. 
Farago pinpointed those differences more precisely by allocating the marriage and household organization patterns of several rural communities in $18^{\text {th }}$-century Hungary to three specific categories: the Western European, the Eastern European, and, finally, the EastCentral European family model (Ostmitteleuropäische Familienmodell) ${ }^{117}$. The latter category was supposed to encompass behavioral patterns representing a transition between the 'NorthWestern European pattern identified by Hajnal and Laslett, and the Russian reality. Capturing the diversification of family forms in the territories of the historical Hungarian Kingdom also remains a leading research goal for contemporary Hungarian historical demography. Both Farago and Öri found a large degree of patchiness of patterns of marriage and household formation across pre-1800 Hungary, which evades classification according to the simple dichotomous model ${ }^{118}$.

\subsection{Polish scholarship}

For the period 1960-2000, there have been a dozen or so works which dealt more directly with the structure of the peasant household during the serfdom period in Poland. Most of these were isolated case studies describing family forms with various typologies devoid of any reference to the models of familial organization developed in the West ${ }^{119}$. Nevertheless, all of them reported more or less unequivocally a decisive predominance of simple family households in the historical Kingdom of Poland between the $16^{\text {th }}$ and $18^{\text {th }}$ centuries, even though the territorial basis of these investigations was limited almost exclusively to the western and southwestern parts of the country ${ }^{120}$. Nonetheless, Polish researchers generally hypothesized that there was a predominance of nuclear households over the whole historical Poland in the Early Modern times, tentatively assuming the existence of different family systems operating on the country's eastern outskirts. Acknowledging the homogeneity of manorial politics and the effect it had on the peasant family, W. Kula proposed that the nuclear family spread over the entirety of the Polish corvee-obliged rural population ${ }^{121}$. Koczerska, in turn, extended the simple family model over the population of nobility, among whom it had replaced more kin-based residential arrangements as early as in the $14^{\text {th }}$ and $15^{\text {th }}$ centuries $^{122}$. With recourse only to a very modest body of data (mostly from the $17^{\text {th }}$ and $18^{\text {th }}$ centuries), Gieysztorowa proposed an operational hypothesis in which she observed that the age at marriage in historical Poland declines on an eastward trajectory, an assumption which was recently authoritatively repeated by $\mathrm{Kuklo}^{123}$. Quite in line with contemporary views offered by other Central European scholars, Gieysztorowa has accentuated the borderline character inherent in the patterns of Polish marital behaviors. This view was supported by 
later, more comprehensive comparative analyses of nuptiality on Polish territories, in which it was argued that the marriage pattern in 18th-century Poland may have been a cross between the Western and Eastern patterns, although much closer to the "unique" North-Western European pattern than to patterns observed in the Hungarian, Russian, and Ukrainian territories $^{124}$.

The hypothesis on the visible nuclearization of family forms throughout the majority of Korona lands in the Early Modern period, which was introduced above, was supplemented by other studies of both rural and urban communities. Kopczynski's study of a few dozen parishes in central and western Poland from between 1650 and 1800 showed that the majority of peasant households had a nuclear structure, and that the relatively high mean size of the domestic group resulted from the spread of hired servants and co-residing lodgers. The marked increase in the number of multi-generational families on the lands covered by his investigation was only brought about by peasant enfranchisement of the second half of the 19th century ${ }^{125}$. Referring to Kuklo's study of six urban communities of the $18^{\text {th }}$ century Polish Crown provided even greater certainty regarding the domination of the simple-family model in central Poland's lands. In the urban centers, the two-generational family was prevalent (making up 66-85 percent of all domestic units), followed by unusually high proportions of solitary households ${ }^{126}$. According to Kuklo, the household structure in the Polish town of the pre-industrial era must be classified as "typically West-European." ${ }^{127}$ For the cluster of rural communities in 18th-century Silesia (today southwestern Poland), Szołtysek found a moderate age at marriage, the dominance of simple-family households, and a high incidence of life-cycle servants. He found strong indications of a stem-family pattern in those places, accompanied by cases in which the modes of household formation did not vary much from the neo-local principles prevalent in North-Western Europe, or which followed exactly this type of pattern ${ }^{128}$. As Szołtysek has argued, if the European great divide in family systems suggested by Hajnal really existed, it was certainly not located in Upper Silesia. It would be necessary to search for it farther to the east ${ }^{129}$.

Indeed, Laszuk concluded that, in the mixed Polish-Belarusian rural areas in the northeastern Polish Crown lands, the domination of the Western type of family was not unambiguous in the late $17^{\text {th }}$ century. By and large, however, the simple family type still occupied a superior position and the share of joint-family-type domestic groups was small, and only among the nobility rose to more than four percent of total households ${ }^{130}$. According to another author, the negligible importance of multi-generational families in the Polish eastern outskirts resulted from the widespread practice among newly married couples of 
gaining economic and residential independence. The individualization of property and residence, the argument goes, was the core organizational principle of the family household on the Polish eastern outskirts, both in the $18^{\text {th }}$ and the $19^{\text {th }}$ centuries. Differences between different ethnic groups (e.g., Poles and Ruthernians) in this regard were supposed to be small $^{131}$.

A more precise identification of the long-expected familial and demographic border in historical Polish territories was attempted in Szołtysek's studies of living arrangements in different regions of Poland-Lithuania (more than 14,000 peasant households fro the $18^{\text {th }}$ century were analyzed ${ }^{132}$. The analysis initially revealed the juxtaposition of a more complex family system in the eastern communities with a homogenous, but simple, family pattern in the western Polish lands. However, a closer look at the data showed that, at the end of the 18th-century, not two but three household and family patterns with substantial numerical and qualitative differences existed in the historical Polish territories. The structural progression within larger regions, Szołtysek demonstrated, nearly always moved in the same direction: i.e., from less kin-centered, more nucleated, and neolocal households in the west; to much more notable levels of household complexity in Poland's more eastern territories. However, even on those eastern outskirts (e.g., in Belarus) the family pattern still differed markedly from paradigmatic examples of the Eastern European family type detected in Russia. These findings were taken as indicative of the existence of a wider Eastern European area with a similar family pattern at the end of the $18^{\text {th }}$ century, with basic commonalities in household size and structure prevalent across Lithuania, Belarus, Red Ruthenia, and western Ukraine; as well as Slovakia and the northern part of Hungary. On the basis of these results, they provided more evidence disputing the assumption that large parts of East-Central Europe were dominated by a homogenous family system. These findings further demonstrated that Hajnal's dichotomous notion of Western and Eastern Europe from around 1900 cannot be transposed onto earlier periods.

\subsection{Family and household studies in Lithuania, Belarus, and Ukraine}

Until recently, Belarusian, Lithuanian, and Ukrainian scholars showed a general lack of interest in studying domestic groups in socio-historical perspective ${ }^{133}$. However, as early as in early 1960s, Višniauskaitė demonstrated that the "grand indissoluble family" (an equivalent to the term "joint family" commonly used in Western terminology) never constituted a dominant household form in ethnic Lithuania between the $16^{\text {th }}$ and the end of the $19^{\text {th }}$ centuries $^{134}$. The nuclearized family system in Lithuania was a direct consequence of lineage relationship 
decomposition, which affected the Baltic countries starting in the $13^{\text {th }}$ and $14^{\text {th }}$ centuries, followed by a marked decline in family communes. Both of these processes were additionally strengthened by the agrarian reforms of the mid- $16^{\text {th }}$ century, which brought about the introduction of the three-field system and the manorial system ${ }^{135}$. An increase in peasant compulsory labor obligations imposed upon them by landlords in $18^{\text {th }}$-century Lithuania caused the accumulation of family labor on the holding, and, in consequence, led to a drastic rise in the share of multiple family households in Lithuania (33 percent of all domestic units in the years 1700-1800). Paradoxically, however, the only moment when in some parts of Lithuania really complex multi-focal families could be found was during the 1930s and 1940 s, that is, when capitalism already was a fact of life ${ }^{136}$.

Some Belarusian scholars applied similar approaches in their handling of the problem of household structure in various Belarusian ethnic territories between the end of the $16^{\text {th }}$ century and the mid- $17^{\text {th }}$ century. Kapyski's analysis of 252 settlements revealed that, on average, one household was comprised of no more than 1.2 conjugal family units, and that more than 85 percent of all households had only one conjugal family unit. Most of the remaining multiple-family domestic groups contained two small families co-residing. Also, in Belarus, the transition from the $16^{\text {th }}$ to the $17^{\text {th }}$ century was marked by an increasing simplification of peasant residential patterns, and one-family households made up the majority of domestic units over the entire Belarusian territory ${ }^{137}$. Referring to a more extensive dataset (over 30,000 peasant hearths), Golubev has proposed a regionalization of family forms in various parts of the Belarussian part of the Grand Duchy of Lithuania at the end of the 16th century, with a major change occuring on a trajectory of movement towards eastern territories. Whereas the proportions of one-family hearths to the general number of peasant households amounted to $73 \%$ in the western part of the region, it dropped to $66 \%$ in the central region, and even to $46,5 \%$ in its eastern part $^{138}$.

Referring to his study of several communities from central Belarus, Nosevich asserted that, based on his review of the $16^{\text {th }}$ century data, there was no reason to draw a sharp distinction between family structures in Eastern and Western Europe. He demonstrated that nuclear-family households were absolutely dominant in Belarus in the second half of the 16th century (between 70 and 89 percent of total households), and that in some places this pattern developed even earlier ${ }^{139}$. At the same time, however, he noted the emergence of a more complex family pattern in central Belarus during the $18^{\text {th }}$ and $19^{\text {th }}$ centuries, which he linked to the gradual increase in feudal obligations imposed on the peasantry by the Eastern European landlords ${ }^{140}$. Nonetheless, over almost the entire $18^{\text {th }}$ century, the rural population 
in Belarus was found to follow a pattern of rather moderate household complexity, which was in marked contrast to the features characteristic of the 19th-century Russia. According to Nosevich, this "balanced" household pattern may have been widespread and persistent in some other parts of Eastern Europe, including northern Lithuania, Ukraine, Estonia, Karelia, and parts of Hungary ${ }^{141}$. Towards the end of the $18^{\text {th }}$ century, the family pattern in Belarus gradually transformed into more communal forms already typical of the vast regions of Russia, with the share of multiple-family households rising significantly above 50 percent. It was this 19th-century phenomenon, but not its various antecedents, that made the distinction between family structures in Eastern and Western Europe so attractive to Western scholars ${ }^{142}$.

The Ukrainian literature on family history brings yet another surprise. The overall description of the Ukrainian family system was drawn up with an emphasis on the powerful drive towards the independence of both individuals and family units in various historical periods, and on the uniquely "nuclear" character of the Ukrainian peasant family ${ }^{143}$. The simple family, it was argued, decisively prevailed in the Ukraine as far back as in the second half of the $19^{\text {th }}$ century, making up an estimated 84 percent of all peasant families ${ }^{144}$. The behavioral dimension of this characteristic was a norm dictating that kinsfolk only occasionally formed joint production and residential units. Even in those cases in which this happened due to poverty or other circumstances, there were no seniority principles, no joint property rights, or concept of the community of work among the co-resident families ${ }^{145}$. Other scholars acknowledged the co-existence of both small and "big, undivided joint-families" in Early Modern Ukrainian lands, but noted that a typical extension strategy involved the addition of only one son who stayed at home in expectation of taking over the farm after the father's death. Moreover, the co-residence of married brothers sometimes encountered in $16^{\text {th }}-$ century Ukraine was generally temporary in character ${ }^{146}$.

While most of the folklore studies were focused on the late 19th century, some authors were suggesting that, in parts of the Ukraine, the "grand patriarchal family" did not actually exist throughout the entire Early Modern period ${ }^{147}$. Quite often, it was argued, those distinct family households were in essence patronimic communities of related persons who frequently cooperated economically on their shared plot of land ${ }^{148}$. Other scholars presented a more variegated picture, and proposed various caesuras to mark the beginning of the spread of the simple-family form across Ukrainian territories. According to some, a more pronounced disappearance of joint families in Ukraine was not seen until the beginning of the $17^{\text {th }}$ century, though the process remained incomplete ${ }^{149}$. According to others, the popularization of singlefamily households in both right- and left-bank Ukraine did not occur until the 1770s or even 
later, although the simple two-generational household definitely became a dominant family type by the mid- $19^{\text {th }}$ century ${ }^{150}$. The risks involved in uncritically transposing the concept of the small nuclear family onto the realities of the period from before the half of the $19^{\text {th }}$ century are clearly indicated by more contemporary historical-demographic research in the Ukraine $^{151}$.

\section{CONCLUDING REMARKS}

A substantial number of the $19^{\text {th }}$ - and $20^{\text {th }}$-century works of family historians, historical demographers, and political economists and sociologists working on demographic issues were concerned with the spatial designations and divisions of Europe. Having been preoccupied with establishing borders, drawing borderlines, and distinguishing between different demographic and family systems in historical and contemporary Europe, scholars of those genres developed their own "symbolic geographies" of the Eastern European demographic space $^{152}$. Early generations of experts in family organization and structure were in the habit of searching for striking contrasts in familial characteristics, and were often prone to speak in terms of dichotomous East-West contrapositions. This tendency to underplay variations in family living arrangements in the European East was criticized even among Western scholars. As early as in 1990s, D. Kertzer argued that "eastern Europe, like western Europe, displayed a diversity of household systems in preindustrial times" which were linked to "regional differences in political economic arrangements and ecological conditions."153

Indeed, the picture of the formation and structure of family forms in vast eastern territories that has been painted in Eastern European historical-demographic literature appears largely incongruent with the postulates of Western scientists. In substantial stretches of Eastern Europe (including territories to the east of the border area suggested by Hajnal) the nuclear-family model was found to have been prevalent, at least during some historical periods. Over substantial sections of this part of the continent-again with the inclusion of some regions from outside the "line"-neo-localism seems to have remained a dominant practice of household formation here and there (e.g., in the Ukrainian lands), undoubtedly constituting the very fabric of a prevalent familial ideology. Contrary to a widely held view, according to which Eastern European complex family patterns supposedly made economic sense for both the Eastern European peasants and the landlords, given the circumstances of refeudalization to which the two sides found themselves subjected ${ }^{154}$, in-depth studies of manorial practices have suggested that seigniorial authority often provided strong incentives for neo-local household formation among the subject farmers. While many scholars showed 
an inclination toward a belief in the geographical diversity of family forms in the European East, others maintained that some "borderlands" strayed from patterns dominant throughout the majority of its territory. The works of Lithuanian and Belarusian scholars clearly indicate that, in some historical periods, the actual differences between the East and the West in terms of the composition of residential groups were much less pronounced than expected, or were even negligible. The spatial and temporal variation in the external forms of familial life, so characteristic of Eastern Europe, is an important argument in favor of jettisoning the concept of the "dividing line" entirely, or of substituting it with the notion of temporally fluent transitional zones which are always unstable and subject to transformations occurring in distinct contexts and for different reasons.

This does not mean, however, that all of the claims of Eastern Europeanists should be accepted uncritically. Eastern European literature on family forms was mainly exiguous. Well into the 1990s, it was screened off from the main current of European thought. The substantive weight of the observations made by these researchers was frequently diminished by the fact that the available source material was researched only cursorily, and by the application of a amethodology largely detached from the mainstream solutions and concepts. The method of deduction from applying examples, instead of undertaking a comprehensive review of the problems, led to the coexistence of conflicting and often irreconcilable perspectives on the issue. The archived material presented to support certain arguments has often left much room for dispute with regard to the accurate categorization of familial forms ${ }^{155}$. With a few notable exceptions (especially the Polish studies appearing since 1967 in the journal Polish Demographic Past), quantification was used only rarely, making the assessment of the representativeness of the presented findings difficult, if not impossible ${ }^{156}$. Most observations were restricted to the serfdom period leaving aside a vast topic of familial behaviors in the post-enfranchisement era ${ }^{157}$. Last but not least, in some national discourses the entire dispute pertaining to the historical roots of various family types has sometimes taken on a highly ideological character.

What is needed here is a research program carefully documenting the contours and variability of household, nuptiality, and life-course patterns for various Eastern European regions by using spatially organized historical statistical data. The essential part of this new agenda would be to identify and differentiate the composition and behavior of multiple subpopulations in a given area or society of Eastern Europe. By revealing significant variations in household formation, marriage, residence patterns and welfare functions of the family group separating these sub-populations, a much more nuanced geography of family patterns, both in 
terms of its spatial and temporal aspects, could be achieved ${ }^{158}$. Instead of utilizing traditional simplistic notions of dividing lines and "ideal family systems," this new scientific program would inevitably adhere to a more sensitive focus on the nature and permeability of frontiers and transition zones, and the ways in which familial and demographic borders have been crossed and diffused, both across space and over time.

It is definitely possible to undertake a research program of this kind for the Eastern European space. We have just begun to take advantage of the ongoing micro-data revolution-i.e., a combination of digitization, Internet access, and harmonization of surviving census and census-like materials-to critically investigate the differences in European historical family systems over space and time (see www.censusmosaic.org). EastCentral Europe-with its mixture of historical legacies, cultural propensities, and ecological factors-will definitely remain at the center of historical debate. A range of comparative projects have been started to provide new insights into the variation and evolution of European family systems and to improve our understanding of the causes underlying their continuity or discontinuity over space and time ${ }^{159}$.

Although partly impressionistic, the findings of Eastern Europeanists discussed above revealed enough diversity of family forms and in the rhythms of their development in historical Eastern Europe to finally free us from a simplistic view of the continent's familial history, and particularly the perspective implied by the notion of a "dividing line." The crux of the argument here is that breaking away from a homogenizing view of Eastern Europe's family and demographic past can help scholars contextualize more thoughtfully recent demographic processes taking place in the eastern part of the continent. It may also serve policy analysts to better understand the role of historical heritage in the socio-political, economic, and demographic currents of the new member states of the European Union, as well as of some potential candidates for membership. In this context, a consideration of particular meanings calls to mind the words of the most cited historian of East-Central Europe, O. Halecki, who wrote back in the 1950s that "one of the main defects of (...) the basic distinction between Western and Eastern Europe lies in the impression obviously created that all of what is geographically 'Eastern' is alien, or even opposed, to 'Western' that is, truly European - civilization" $" 160$. Historical studies of the family can draw lessons from these insights. 


\section{Acknowledgements}

An earlier version of this article was presented at the 35th Social Science History Association Annual Conference, Chicago, November 2010, in the session "In homage of Richard Wall and the 25th anniversary of Continuity \& Change: Household, family and marriage across time and space." I wish to thank Andrejs Plakans and one anonymous reviewer for their valuable comments.

\footnotetext{
${ }^{1}$ For example: Goran Therborn, Between Sex and Power: Family in the World 1900-2000 (London, 2004); Arland Thornton, Reading history sideways. The fallacy and enduring impact of the developmental paradigm on family life (Chicago, 2005); Hannes Grandits, 'Introduction: the reshaping of family and kin relations in European welfare systems', in Hannes Grandits, ed., Kinship and social security in contemporary Europe, vol. 1. Family, kinship and state during the century of welfare: eight countries (Frankfurt/New York, 2010), 23-46.

${ }^{2}$ Maria Todorova, ' On the epistemological value of family models: the Balkans within the European pattern', in Maria Todorova, Balkan Family Structure and the European Pattern. Demographic Developments in Ottoman Bulgaria (Washington, DC, 2006), 199-211; Silvia Sovic, 'Moving Beyond Stereotypes of 'East' and 'West', Cultural and Social History 5, 2 (2008), 141-163; Andrejs Plakans and Charles Wetherell, 'The Hajnal line and Eastern Europe', in Theo Engelen, and Arthur P.Wolf, eds., Marriage and the family in Eurasia. Perspectives on the Hajnal hypothesis (Amsterdam, 2005), 105-126); David I. Kertzer, 'Household history and sociological theory', Annual Review of Sociology 17 (1991), 155-179.

${ }^{3}$ Recently, for example, Tomáš Sobotka, 'The diverse faces of the Second Demographic Transition in Europe', in Tomas Frejka, Tomáš Sobotka, Jan M. Hoem eds., Childbearing trends and policies in Europe, Demographic Research 19, Article 8 (2008), 171-224.

${ }^{4}$ This paper is restricted primarily to a discussion of East-Central European area studies. Consequently, it takes only a very limited stance on intense discussions among the $19^{\text {th }}$-century scholars of the morphology and social implications of the peculiar family type of zadruga, found in some parts of the Balkans, but often believed to encapsulate the very spirit of the Slavic familial tendencies (reviewed in Mikołaj Szołtysek and Barbara ZuberGoldstein, 'Historical family systems and the great European divide: the invention of the Slavic East', Demográfia: English Edition 52, 5 (2009), 5-47. The variety of family forms in pre-industrial Russia is also omitted here.

${ }^{5}$ Larry Wolff, Inventing Eastern Europe: The map of civilization on the mind of the enlightenment (Stanford, 1994).

${ }^{6}$ August von Haxthausen, Studien über die inneren Zustände, das Volksleben und insbesondere die ländlichen Einrichtungen Rußlands (Hanower-Berlin, 1972[1846]), 82.

${ }^{7}$ P. Perier, 'Le Play and his followers: over a century of achievement', International Social Science Journal 50, 157 (2002), 6; Thornton, Reading history sideways, 64; also E. Adamovsky, 'Russia as a Space of Hope: Nineteenth-Century French Challenges to the Liberal Image of Russia', European History Quarterly 33, 4 (2003), 424.

${ }^{8}$ Frédéric Le Play, L'organisation de la famille selon le vrai modele signale par l'histoire de toutes les races et de tous les temps, $3^{\text {rd }}$ edn. (Tours: 1871), $§ 12$, 94; Frédéric Le Play, 'Le Réforme Sociale', in C. Bodard Silver ed., Frederic Le Play on Family, Work, and Social Change (Chicago: 1982[1872]), 259.

${ }^{9}$ Frédéric Le Play, Les Ouvriers Européens (Tours: 1877-1879), vol. I, facing p. 683.

${ }^{10}$ Despite placing this line in his mapping exercise, Le Play never referred to it directly in the text.

${ }^{11}$ Le Play, Les Ouvriers Européens, v. 2.

${ }^{12}$ Thornton, Reading history sideways, 61; Emmanuel Todd, The explanation of ideology. Family structures and social systems (Oxford, 1985). Le Play's model of European family structures has been verified by a large battery of family research conducted in the second half of the 20th century. This research was not, however, focused on his geographic premises, but on his developmental trajectory interpretations (see Peter Laslett, 'Introduction', in Peter Laslett and Richrd Wall eds., Household and family in past time (Cambridge, 1972), 189).

${ }^{13}$ For example Laslett, 'Introduction'.
} 
${ }^{14}$ John Hajnal, 'European marriage patterns in perspective', in David V. Glass and David E. C. Eversley eds., Population in history. Essays in historical demography (London, 1965), 101-143.

${ }^{15}$ Hajnal compared data from different part of the European continent (including European Russia) with surveys of Asian and even African societies. Hajnal's basic unit of analysis were national societies, although his secondary data may have referred to single regions or even locations.

${ }^{16}$ Hajnal, 'European marriage patterns', 101.

${ }^{17}$ Hajnal was less certain, however, as to where to put the line between "East" and "West" in terms of percentages never maried (see Francois Hendrickx, 'West of the Hajnal line: North-western Europe', in Engelen and Wolf, Marriage and the family in Eurasia, 78).

${ }^{18}$ Hajnal, 'European marriage patterns', 101.

${ }^{19}$ Hajnal, 'European marriage patterns', 104.

${ }^{20}$ Peter Laslett, The world we have lost (London, 1965), 90-91.

${ }^{21}$ Peter Laslett, The world we have lost, $2^{\text {nd }}$ edition (London, 1965), 94.

${ }^{22}$ Peter Laslett, 'The comparative history of household and family', Journal of Social History 4, 1 (1970), 81-82.

${ }^{23}$ Laslett made reference to the data from Estonia ('At the other end of Western Europe, in an Esthonian village'; Laslett, 'Introduction', 20, also ft. 35) as revealing features compatible with stem family rules, although a careful reading of that passage suggests he may rather have had in mind a joint-family system with married brothers living together. He also mentioned some Latvian and Hungarian territories of the 18th century as having the highest proportions of multiple households in pre-industrial Europe, but without making either a geographical or a bibliographical reference (Laslett, 'Introduction', 60-61, ft. 79). Finally, at least twice, he referred to microcensus data from a village Lesnica in "far away Poland;" again, no careful reference was provided, and Laslett admitted that the data could not be taken as representing "the whole national area" (Laslett, 'Introduction', 62).

${ }^{24}$ Peter Laslett, 'Characteristics of the Western family considered over time', in Peter Laslett, Family life and illicit love in earlier generations. Essays in historical sociology (Cambridge, 1977), 12-49. The paper was first circulated in an unpublished version in 1973 and was consequently revised and expanded for publication in 1977.

${ }^{25}$ Laslett, 'Characteristics of the Western family', 14-16.

${ }^{26}$ These were isolated points (seven geographically disparate case studies) for which research results have been available, giving way to regional or national designations/references.

${ }^{27}$ Laslett, 'Characteristics of the Western family', 16-17, 22-23; also Peter Laslett, 'The stem-family hypothesis and its privileged position', in Kenneth W. Wachter, Eugene A. Hammel and Peter Laslett, Statistical studies of historical social structure (New York, 1978), 90-93.

${ }^{28}$ In some communities of this area, Laslett asserted, "entirely 'Western' familial patterns seemed to have existed in villages next door to others [sic!] where the pattern was less pronounced, and where elements of other systems obtruded (...) In individual places in this large and ragged region simple family households predominated, accompanied by others of the characteristics we have listed (...) But in others as late as the eighteenth and early nineteenth centuries, 'non-Western' familial characteristics (as here defined) were even more pronounced than those which have been found in the small group of Serbian and Japanese communities known to us at the same time, though never as extreme as in Great Russia (...)" (Laslett, 'Characteristics of the Western family', 16-17).

${ }^{29}$ Laslett, 'Characteristics of the Western family', 27.

${ }^{30}$ Laslett, 'Characteristics of the Western family', 14.

${ }^{31}$ Both Hajnal's and Laslett's perception of family type in Eastern Europe seemed to have been deeply influenced by P. Czap's findings; see Laslett, 'Characteristics of the Western family', 12, 14, 22-23, 27; Laslett, 'The stem-family hypothesis', 91; Peter Laslett, 'Family and household as work group and kin group: areas of traditional Europe compared', in Richard Wall and Jean Robin eds., Family forms in historic Europe (Cambridge, 1983), 517, 520-521, 549; Peter Laslett, 'Family, kinship and collectivity as systems of support in preindustrial Europe: a consideration of the »nuclear-hardship« hypothesis', Continuity and Change 3, 2 (1988), 156-159; John Hajnal, 'Two kinds of preindustrial household formation system', Population and Development Review 8, 467-469, 473. Preliminary results of research on the Mishino estate were circulated within a close-knit community of scholars before they finally came into print, and were available to Laslett certainly before 1977 .

${ }^{32}$ Peter Czap, 'The perennial multiple family household, Mishino, Russia, 1782-1858', Journal of Family History, 7, 18; Peter Czap, "»A large family: the peasant's greatest wealth «: Serf households in Mishino, Russia, 1814-1858', in Wall and Robin, Family forms in historic Europe, 145 ff.

${ }^{33}$ Peter Czap, 'Marriage and the Peasant Joint Family in Russia', in David Ransel ed., The Family in Imperial Russia (Urbana, 1978), 114, 116.

${ }^{34}$ Czap, 'The perennial multiple family', 6 .

35 "It is true," Czap wrote, "that large households, or preferably housefuls, were found elsewhere in northeastern Europe in the eighteenth and nineteenth centuries, especially in the Baltic provinces of the Russian Empire. But 
the composition of the large Baltic domestic units, and of smaller Polish ones as well, extended to servants, farmhands, and other non-related persons rarely encountered in the almost exclusively kin-based households revealed by the data used in this study" (Czap, 'The perennial multiple family', 7). Sources of data on Polish and Baltic households were not provided in the text.

${ }^{36}$ Czap, '»A large family: the peasant's greatest wealth«', 146-148, 150.

${ }^{37}$ Sovic, 'Moving Beyond Stereotypes', 144.

${ }^{38}$ Hajnal, 'Two kinds', 452.

39 'Indeed it seems likely that something like the Mishino household formation system prevailed among populations numbering in the millions' (Hajnal, 'Two kinds', 468).

${ }^{40}$ Hajnal, 'Two kinds', 469.

${ }^{41}$ See Laslett, 'Family and household', 516, 526-527.

${ }^{42}$ Laslett, 'Family and household', 529. The lack of specification of spatial reference to "European Russia as a whole" disclosed Laslett's lack of concern about the diversity of Eastern European family patterns. It goes without saying that, depending on the level of inclusiveness of the category "European Russia as a whole," one ends up with strikingly different geographical patterns of family types in Eastern Europe.

${ }^{43}$ Laslett, 'Family and household', 528.

${ }^{44}$ For example Milan Kundera, 'The tragedy of Central Europe', New York Review of Books 31, 7 (1984), $33-38$.

${ }^{45}$ A close reading of yet another comparativist endeavor as put forward by R. Wall (Laslett's long-term close collaborator) suggests that the term "Central Europe" was most often used to refer to countries such as Austria, Hungary, Czechoslovakia, the German Democratic Republic, and Poland. However, the "centrality" of the positioning of Austria was clearly accentuated (Richard Wall, 'Introduction', in Wall and Robin, Family forms in historic Europe, 38, 44, 48.

${ }^{46}$ Edward A. Wrigley, 'Reflections on the History of the Family', Daedalus 106 (1977), 78.

${ }^{47}$ A. Burguière and F. Lebrun, 'Les Cent et une familles de l'Europe', in A. Burguière et.al. eds., Historire de la Famille, vol. 2. (Paris, 1986), 38.

${ }^{48}$ Andrejs Plakans, 'Agrarian Reform in the Family in Eastern Europe', in David I. Kertzer and Marzio Barbagli eds., Family Life in the Long Nineteenth Century 1789-1913. The History of the European Family, Volume 1 (New Haven and London, 2002), 79; other variants of a similar approach in A. Burguière, 'Historical foundations of family structures', in J. Commaille and F. de Singly eds., The European family. The family question in the European Community (Dordrecht, 1997), 105-107; A. S. Alderson and S.K. Sanderson, 'Historic European household structures and the capitalist world-economy', Journal of Family History 16, 4 (1991), 419432; David S. Reher, 'Family ties in Western Europe: persistent contrasts', Population and Development Review 4, 2 (1998), 204; Karl Kaser, 'Serfdom in Eastern Europe', in David I. Kertzer and Marzio Barbagli eds., Family Life in Early Modern Times 1500-1789. The History of the European Family, Volume 1 (New Haven and London, 2001), 34; Antoinette Fauve-Chamoux, 'Marriage, Widowhood, and Divorce. In Kertzer and Barbagli, Family Life in Early Modern Times, 221; Thornton, Reading history sideways, 52.

${ }^{49}$ Therborn, Between Sex and Power, 305.

${ }^{50}$ C. Grassland, 'Systèmes démographiques et systèmes supra-nationaux: la fécondité européenne de 1952 à 1982', Revue Européenne de Démographie 2 (1990), 163-191; A. Blum and J.-L. Rallu, 'European population', in A. Blum and J.-L. Rallu eds., European Population, vol. 2: Demographic dynamics (Montrouge, 1993), 1-48; A. Monnier, and J. Rychtarikova, 'The division of Europe into East and West', Population: An English Selection 4 (1992), 129-159; J. Rychtarikova, 'Nuptialité comparée en Europe de l'Est et en Europe de l'Ouest', in Blum and Rallu, European Population, vol. 2, 191-210; D. Philopov, 'Possible explanations of demographic changes in central and eastern Europe', in D. Philipov and J. Dorbritz, Demographic Consequences of Economic Transition in Countries of Central and Eastern Europe (Strasbourg, 2003), 151-164; T. Sobotka, 'Re-Emerging Diversity: Rapid Fertility Changes in Central and Eastern Europe After the Collapse of the Communist Regimes', Population-E 58, 4-5 (2003), 475.

${ }^{51}$ F. Höllinger and M. Haller, 'Kinship and Social Networks in Modern Societies: A Cross-Cultural Comparison among Seven Nations', European Sociological Review 6 (1990), 103-124; B. Nauck, 'Value of Children and the Framing of Fertility: Results from a Cross-cultural Comparative Survey in 10 Societies', European Sociological Review 23 (2007), 615-629; K. Kaser, Familie und Verwandschaft auf der Balkan. Analyse einer untergehenden Kultur (Wien, 1995); K. Kaser, Macht und Erbe. Männerschft, Besitz und Familie im östlichen Europa (15001900) (Wien, 2000); P. Heady, 'Introduction - care, kinship and community', in P. Heady and P. Schweitzer eds., Kinship and social security in contemporary Europe, vol. 2. Family, kinship and community at the start of the $21^{\text {st }}$ century: nieneteen localities (Frankfurt/New York, 2010), 13-59; P. Heady, S. Gruber, and T. Bircan, 'The quantitative background', in Heady and Schweitzer, Kinship and social security, 61-90.

${ }^{52}$ N. Keilman, 'Recent trends in family and household composition in Europe', European Journal of Population 3 (1987), 297-325; A. C. Kuijsten, A.C., 'Changing Family Patterns in Europe: A Case of Divergence?', European Journal of Population 12 (1996), 115-143; K. Schwarz, 'Household trends in Europe after World War 
II', in N. Keilman, A.C. Kuijsten and A. Vossen eds., Modelling household formation and dissolution (Oxford, 1988), 67-83; S. De Vos and G. Sandefur, 'Elderly Living Arrangements in Bulgaria, The Czech Republic, Estonia, Finland, and Romania', European Journal of Population/Revue européenne de Démographie 18, 1 (2002), 21-38; P. Ahmed and R. Jean Emigh, 'Household composition in post-socialist Eastern Europe', International Journal of Sociology and Social Policy 25, 3 (2005), 9-41; M. Iacovou and A. J. Skew, 'Household composition across the new Europe: Where do the new Member States fit in?, Demographic Research 25, 14 (2011), 465-490.

${ }^{53}$ R. Wall, 'Regional and temporal variations in English household structure from 1650', in J. Hobcraft and P. Rees eds., Regional demographic development (London, 1979), 89-113.

${ }^{54}$ Wall, 'Regional and temporal variations, 89.

${ }_{55}^{55}$ Wall, 'Regional and temporal variations, 93-98.

${ }^{56}$ Wall, 'Regional and temporal variations, 109.

${ }^{57}$ R. Wall, 'European family and household systems', in Historiens et populations. Liber Amicorum Etienne Helin (Louvain-la-Neuve, 1991), 619.

${ }^{58}$ Rural populations only.

${ }^{59}$ Wall, 'European family and household systems', 619-620.

${ }^{60}$ Wall, 'European family and household systems', 625; partly repeated in R. Wall, 'Historical development of the household in Europe', in E. van Imhoff, A.C. Kuijsten, P. Hooimeijer, and L.J.C. van Wissen eds., Household Demography and Household Modeling (New York, 1995), 32-37.

${ }^{61}$ R. Wall, 'Transformation of the European family across the centuries', in R. Wall, T. K. Hareven, J. Ehmer and M. Cerman eds., Family history revisited. Comparative perspectives (Newark, 2001), 217-241.

${ }^{62}$ Wall, 'Transformation', 221, 224.

${ }^{63}$ Wall, 'Transformation', 236-237.

${ }^{64}$ A. Plakans, A. 'Peasant Families East and West: A Comment on Lutz K. Berkner's Rural Family Organization in Europe', Peasant Studies Newsletter 2 (1973), 11-16; A. Plakans, 'Seigneurial Authority and Peasant Family Life: The Baltic Area in the Eighteenth Century', Journal of Interdisciplinary History 5, 4 (1975), 629-654.

${ }^{65}$ Plakans, A. 'Peasant Families East and West', 13; Plakans, 'Seigneurial Authority', 645.

${ }^{66} \mathrm{~J}$. Sklar, 'The role of marriage behaviour in the demographic transition: the case of Eastern Europe around 1900', Population Studies 28 (1974), 231-247. Sklar was a student of Kingsley Davis at Berkeley, where she got her $\mathrm{PhD}$ in 1970. She died prematurely in 1977.

${ }^{67}$ Sklar, 'The role of marriage behaviour', 232-234; also tab. 6, 245. Sklar contended that the 36.3 percent who had never married at ages 20 to 29 , and the 7.8 per cent never married at ages 40 to 49 among females in the Polish areas, 'still reflect a rather late age at marriage and moderately high celibacy, especially compared with the Balkan countries'.

${ }^{68}$ Sklar, 'The role of marriage behaviour', 234-236. Sklar's information on Polish customs were derived mostly from the work of Thomas and Znaniecki (see ft. 7, 235).

69 "Although people were not marrying as late in such areas as Grodno, Volhynia [northern Belarus, and the northwest corner of Ukraine] and Slovakia as in Western Europe, mean age at first marriage was higher than in the early marriage Balkan countries of Bulgaria, Romania and Serbia" (Sklar, 'The role of marriage behaviour', 234).

${ }_{70}$ This genuine contribution to historical demography of Eastern Europe went generally unnoticed by mainstream scholars working on a geography of family forms and was not mentioned in any work of the Cambridge Group-related scholars known to me (but see A. Plakans, A. 'Interaction between the household and the kin group in the eastern European past: posing the problem', Journal of Family History 12 (1987), 166; Kertzer, 'Household history', 163; M. Ni Bhrolchain, 'Est-West marriage contrasts, old and new', in Blum Rallu, European Population, vol. 2, 461-462). Scholars from Eastern Europe rarely recognize the importance of Sklar's paper, and only most recently (G. Kera and E. Pandelejmoni, 'Marriage in urban Albania (during the first half of the twentieth century)', History of the Family 13, 2 (2008), 126-137; A. Pamporov, 'Patterns of family formation: Marriage and fertility timing in Bulgaria at the turn of the twenty-first century - A case-study of Sofia', History of the Family 13, 2 (2008), 210-221.

${ }^{71}$ H. Chojnacka, 'Nuptiality Patterns in an Agrarian Society', Population Studies 30, 2 (1976), 204-205.

${ }^{72}$ Chojnacka, 'Nuptiality Patterns', 211.

${ }^{73}$ A. J. Coale, B. A. Anderson, and Erna Härm, Human Fertility in Russia since the Nineteenth Century (Princeton, 1979).

${ }^{74}$ Coale, Anderson and Härm, Human Fertility, 136-139.

${ }^{75}$ Coale, Anderson and Härm, Human Fertility, 148-153. The diversity of family and marriage patterns within Russian political boundaries has been noted by studies at the regional level too (see for example, M. Polla, 'Family systems in central Russia in the 1830s and 1890s', History of the Family 11 (2006), 27-44). 
76 J. Ehmer, Heiratsverhalten, Sozialstruktur, ökonomischer Wandel. England und Mitteleuropa in der Formationsperiode des Kapitalismus (Göttingen, 1991).

${ }^{77} \mathrm{Up}$ to the turn of the $18^{\text {th }}$ century, Galicia (Galizien in German) constituted a historical region of Red Ruthenia south and southeast from the province of Lesser Poland, in the Polish-Lithuanian Commonwealth. After the $18^{\text {th }}$ century partitions of Poland, it became a Crown Land of the Austro-Hungarian monarchy, located in its northeastern corner.

${ }^{78}$ Data used by Ehmer (various volumes of Österreichische Statistik) contained information on marital status by age only for males.

${ }^{79}$ Ehmer, Heiratsverhalten, 144-148.

${ }^{80} \mathrm{M}$. Cerman, 'Central Europe and the European marriage pattern. Marriage patterns and family structure in Central Europe, 16th-19th centuries', in Wall, Hareven, Ehmer and Cerman, Family history revisited, 283-285; also M. Cerman, 'Mitteleuropa und die «europäischen Muster». Heiratsverhalten und Familienstruktur in Mitteleuropa, 16.-19. Jahrhundert', in J. Ehmer, T.K. Hareven and Richard Wall eds., Historische Familienforschung: Ergebnisse und Kontroversen. Michael Mitterauer zum Geburtstag (Frankfurt am Main, 1997), 327-346.

${ }^{81}$ Cerman, 'Central Europe', 301-302. Still, however, it is hard from Cerman's analysis to identify more precisely where this transitional zone was located (apart from that it covered Slovakian areas), which other territories it had cut through while repositioning others to different typological entities.

${ }^{82}$ M. Todorova, 'Population structure, marriage patterns, family and household (according to Ottoman documentary material from north-eastern Bulgaria in the 60s of the 19th century)', Etudes balkaniques 1 (1983), 59-72; M. Todorova, 'Situating the family of Bulgaria within the European pattern', History of the Family 1 (1996), 443-459; Todorova, 'On the epistemological value'.

${ }^{83}$ Todorova, 'Population structure', 71-72.

${ }^{84}$ Todorova, 'On the epistemological value', 105-108; cit. 105. The predominance of nuclear households was also reported for Macedonia (E. A. Hammel, 'Household structure in fourteenth-century Macedonia', Journal of Family History 5 (1980), 242-273), and Slovenia (S. Sovic, 'Families and Households of the Poor: Day Labourers in Nineteenth-Century Slovenia', History of the Family 19 (2006), 161-182). Depending on the socioeconomic setting, different household systems were observed in northern Croatia, one of them being based on the predominance of nuclear households (J. Capo-Zmegac, 'New evidence and old theories: multiple family households in northern Croatia', Continuity and Change 11, 3 (1996), 375-398). Exceptions to this rule are given in K. Kaser, 'The Balkan joint family: redefining a problem', Social Science History 18, 2 (1994), 257, 261; Kaser, Familie und Verwandschaft, 265-338. Kaser also gives the most thorough assessment of the Balkan household types' internal variation (see K. Kaser, 'Introduction: Household and Family Contexts in the Balkans', History of the Family 1, 4 (1996), 375-386, esp. 380). According to him, the Bulgarian family pattern Todorova focused on represented only the transitional form from the more complex nature of family residential arrangements in the Balkan interior (ibid., 383).

85 S. Gruber, 'Household formation and marriage: different patterns in Serbia and Albania?', in A. FauveChamoux and I. Bolovan eds., Families in Europe between the 19th and 21st centuries: from the traditional model to contemporary PACS (Cluj-Napoca, 2009), 229-248; see also S. Gruber, and M. Szołtysek, 'Stem families, joint families and the 'European pattern': what kind of a reconsideration do we need?', Journal of Family History 37,1 (2012, forthcoming).

${ }^{86}$ M. Mitterauer, 'Family contexts: the Balkans in European comparison', History of the Family 1, 4 (1996), 404.

${ }^{87}$ M. Szołtysek, 'Three kinds of preindustrial household formation system in historical Eastern Europe: A challenge to spatial patterns of the European family', History of the Family 13, 3 (2008), 223-225.

${ }^{88}$ Szołtysek, 'Three kinds', 223-257.

${ }^{89}$ For example E. A. Hammel, 'Reflections on the Zadruga', Ethnologia slavica. Zbornik filozofickej fakulty univerzitety Komenskeho 7 (1975), 141-151.

${ }^{90}$ Szołtysek and Zuber-Goldstein, 'Historical family systems'.

91 For example A. Macfarlane, 'Demographic structures and cultural regions in Europe', Cambridge Anthropology 6, 1-2 (1980), 1-17.

${ }^{92}$ K. Kadlec, Rodinny nedil ćili zadruha v pravu slovanskem (Praha, 1898), 1-3, 129-132. Other "universal" features of "niedzial" forms included: seniority principle in the succession of headship; strong standing of widowed mothers as household heads (in other cases, the position of women in zadrugal forms was usually only secondary); the domination of the patrilineal descent ideology and practice, also underscored by norms of equal partible inheritance among the male offspring or lateral relatives and ultimogeniture (in cases when splitting occurred); and patriarchal power relations.

${ }^{93}$ For the more contemporary notion of a much earlier disappearance of the zadruga type families among the Western Slavs (Poles, Czechs, Slovaks, and also Slovenians) see also M. Gimbutas, The Slavs (New York, 1971), 136. 
${ }^{94}$ Kadlec, Rodinny nedil, 1-2, 10, 49, 53, 75, 100-107, 125, 130.
${ }^{95}$ Kadlec, Rodinny nedil, 75, 106, 117-119, 125, 130.
96 O. Balzer, 'O zadrudze słowiańskiej. Uwagi i polemika', Kwartalnik Historyczny 13, 2 (1899), 185, 193, 241-
${ }^{242 .}$
${ }^{97}$ Balzer, 'O zadrudze słowiańskiej', 191-199.
${ }^{98}$ H. Łowmiański, Zaludnienie państwa litewskiego w wieku XVI. Zaludnienie w roku 1528. Ed. by A. Kijas and K. Pietkiewicz (Poznań, 1998), 101-113, 132, 150-152.

${ }^{99}$ H. Łowmiański, Z dziejów Stowian w I tysiącleciu n.e. (Warszawa, 1967).

${ }^{100}$ Bujak suggested that huge, lineage-based families among peasantry of southern Poland vanished by the 12 th and 13th centuries. According to Bujak, this process was a result of the landowners' policy of support of the "innate drive" towards the individualization of family relationships among peasant population, with a view to multiplying their own profits, which were usually calculated on the basis of single households number (F. Bujak, Studia nad osadnictwem Małopolski (Poznań, 2001[1905]), 111.

${ }^{101}$ Łowmiański, Z dziejów Stowian, 357-358.

${ }^{102}$ Łowmiański, Z dziejów Stowian, 346-350.

${ }^{103}$ Łowmiański, Z dziejów Stowian, 360-362.

${ }^{104}$ E. Čaňová, P. Horska, and E. Maur, 'Les listes nominatives de la Boheme, source de donnees pour l'histoire sociale et la demographie historique', Annales de demographie historique 24 (1987), 295-312; J. Grulich, H. Zeitlhofer, 'Struktura jihočeských venkovských a městských domácností v 16. a 17. století. (Příspěvek k dějinám sociální každodennosti poddaných v období raného novověku)', Historicka demografie 23 (1999), 36-40. Soupis was drawn up in 1651 by the Habsburg monarchy in the form of a register of households.

${ }^{105}$ P. Horska, 'K historickemu modelu stredoevropske rodiny', Demografie 31, 2 (1989), 137-143;

E. Čaňová and P. Horska, 'Existuje stredoevropsky model rodiny pro predstatisticke obdobi?', in Z. Pavlik ed., Snatecnost a Rodina: Brachnost i Semia (Praha, 1992), 90-104; Grulich and Zeitlhofer, 'Struktura jihočeských', 51-52; J. Langer, 'Household - social environment - ecotypes', Ethnologia Europe Centralis 2 (1994), 44.

${ }^{106}$ Horska, 'K historickemu modelu'; also Čaňová and Horska, 'Existuje stredoevropsky model'.

${ }^{107}$ Horska, 'K historickemu modelu', 142; P. Horska, 'Historical Models of the Central European Family: Czech and Slovak Examples', Journal of Family History 19, 2 (1994), 101, 104.

${ }^{108}$ Horska, 'K historickemu modelu'; Čaňová and Horska, 'Existuje stredoevropsky model', 102; J. Horský and E. Maur, 'Die Familie, Familienstrukturen und Typologie der Familien in der böhmischen Historiographie', Historicka demografie 17 (1993), 13; J. Horský and M. Sladek, 'Rodinné, sociální a demografické poměry v poddanských vsích na panství Třeboň v letech 1586 a 1651', Historická demografie 17 (1993), 83; also: E. Rumlova, 'Demograficka a socialni struktura obyvatelstva panstvi Dymokury v polovine 17. Stoleti', Historicka demografie 17 (1993), 153-200; M. Seligová, 'Příspěvek ke studiu rodinných struktur v Čechách v 17. století. Panství Děčín - sonda', Historická demografie 17 (1993), 111-130; Grulich and Zeitlhofer, 'Struktura jihočeských'.

${ }^{109}$ Horska, 'K historickemu modelu', 142; Horska, 'Historical Models', 101-104; Horský and Maur, 'Die Familie', 14-15; Čaňová and Horska, 'Existuje stredoevropsky model', 94-95; Langer, 'Household - social environment', 44-45; also S. Švecová, 'Dva typy tradicnej ceskoslovenskej rodiny v Ceskoslovensku', Ceský lid 76 (1989), 215). Some scholars comparing $16^{\text {th }}$ - and $17^{\text {th }}$-century Bohemian household lists have, however, argued that in the late $16^{\text {th }}$ century (1586) no relics of the "Eastern" family structure could be found. Consequently, no marked turning point from one family system to another was possible to detect in Bohemia between 1586 and 1651 (Horský and Sladek, 'Rodinné, sociální a demografické', 81-82, 85).

110 Čaňová and Horska, 'Existuje stredoevropsky model', 90-94; Horska, 'Historical Models', 102; Švecová, 'Dva typy tradicnej', 211.

111 Švecová, 'Dva typy tradicnej’, esp. 215-216; also S. Švecová, 'Klasifikácia rodinných foriem na slovenskom materiáli', Ceský lid 53 (1966), 85-89; S. Švecová, 'Slovenská a ceská rodina', Ceský lid 73 (1986), 203-205). In Švecová's accounts, "rodina jednonástupnická" which came to be prevalent in Bohemia, represented an equivalent of Le Play’s famille souche (Švecová, 'Dva typy tradicnej', 210, 215).

112 Švecová, 'Klasifikácia rodinných foriem', 86-87; Švecová, 'Slovenská a ceská rodina', 203; Švecová, 'Dva typy tradicnej', 212-215; also Horský and Sladek, 'Rodinné, sociální a demografické', 71-71, 81-82.

113 Švecová, 'Dva typy tradicnej’, 214-217.

114 Švecová, 'Slovenská a ceská rodina', 204. Complex and almost self-sufficient family collectives did not dominate the region of Slovakia entirely, but their incidence was connected with the variety of local ecotypes.

${ }^{115} \mathrm{R}$. Andorka, 'The peasant family structure in the $18^{\text {th }}$ and $19^{\text {th }}$ centuries (data from Alsónyék and Kölked in international comparison)', Acta Ethnographica Academiae Scientiarum Hungaricae 25, 3-4 (1976), 344.

${ }^{116}$ R. Andorka and T. Farago, 'Pre-industrial household structure in Hungary', in Wall and Robin, Family forms, 294.

${ }^{117}$ T. Farago, 'Formen bäuerlicher Haushalts- und Arbeitsorganization in Ungarn um die Mitte des 18. 
Jahrhunderts', in J. Ehmer and M. Mitterauer eds., Familienstruktur und Arbeitsorganisation im ländlichen Gesellschaften (Graz, 1986), 135 ff.

${ }^{118}$ T. Farago, 'Different household formation systems in Hungary at the end of the $18^{\text {th }}$ century: variations on John Hajnal's thesis', Historical Social Research 1-2 (1998), 83-111; T. Farago, 'Different household formation systems in Hungary at the end of the $18^{\text {th }}$ century: variations on John Hajnal's thesis', Demográfia, Special Edition 46 (2003), 95-136; P. Öri, 'Marriage Customs and Household Structure in Hungary at the end of the 18th Century. The Case of County Pest-Pilis-Solt (1774-1785)', in Fauve-Chamoux and Bolovan, Families in Europe, 167-192.

${ }^{119}$ For ex ample, E. Brodnicka, 'Ludność parafii Wieleń nad Notecią w drugiej połowie XVIII w.', Przeszłość Demograficzna Polski 2 (1969), 177-215; S. Borowski, 'Próba odtworzenia struktur społecznych i procesów demograficznych na Warmii u schyłku XVIIw. na przykładzie Dobrego Miasta i okolicy', Przeszłość Demograficzna Polski 8 (1975), 125-198; S. Borowski, 'Procesy demograficzne w mikroregionie Czacz w latach 1598-1975', Przeszłość Demograficzna Polski 9 (1976), 95-191; M. Górny, 'Wartość źródłowa „status animarum” parafii Szaradowo z 1766 r.', Przesztość Demograficzna Polski 17 (1987), 165-184; M. Górny, 'Rodzina chłopska i jej gospodarstwo w Wielkopolsce w drugiej połowie XVIII wieku', in M. Górny, Mieszkańcy parafii pepowskiej w 1777 roku. Analiza ksiegi status animarum (Wrocław, 1994), 111-119; L. Polaszewski, 'Struktura społeczna ludności w parafii Szubin w 1766 roku', Przeszłość Demograficzna Polski 10 (1978), 157-175; Z. Kwaśny, 'Rodzina chłopska w parafii Dobra w latach 1727-1758', in H. Suchojad ed., Wesela, chrzciny i pogrzeby w XVI-XVIII wieku. Kultura życia i śmierci (Warszawa, 2001), 23-31. It was only during the 1990s that the Cambridge Group's methodology was comprehensively introduced in Poland (C. Kuklo, 'Problematyka badawcza europejskiej demografii historycznej w dziesięcioleciu 1975-1985', Przesztość Demograficzna Polski 18 (1991), 93-115; C. Kuklo, and W. Gruszecki, Informatyczny system rekonstrukcji rodzin, gospodarstw domowych i społeczności lokalnych w Polsce przedrozbiorowej (Białystok, 1994).

${ }^{120}$ Z. Kwaśny, 'Struktura demograficzna ludności wiejskiej w kluczu Gryf w drugiej połowie XVIII wieku i na początku XIX wieku', Ślaski Kwartalnik Historyczny Sobótka 21, 1 (1966), 103-123; W. Obraniak, 'Oblicze demograficzne wsi wieluńskiej w epoce Sejmu Wielkiego', Studia Demograficzne 16 (1968), 109-122; B. Wachowiak, 'Rodzina chłopska na Pomorzu Zachodnim w połowie XVIII wieku', Przeszłość Demograficzna Polski 18 (1990), 139-48; M. Kopczyński, Studia nad rodzina chtopska w Koronie w XVII-XVIII wieku (Warszawa, 1998); C. Kuklo, Kobieta samotna w spoteczeństwie miejskim u schytku Rzeczypospolitej szlacheckiej. Studium demograficzno-społeczne (Białystok, 1998).

${ }^{121}$ W. Kula, 'La seigneurie et la famille paysanne en Pologne au XVIII siècle', Annales E. S. C. 27 (1972), 949958.

${ }^{122}$ M. Koczerska, Rodzina szlachecka w Polsce późnego średniowiecza (Warszawa, 1975), 100-109.

${ }^{123}$ I. Gieysztorowa, 'Sprawozdanie z konferencji poświęconej zastosowaniu technik komputerowych w badaniach historyczno-demograficznych XVII i XVIII w.', Przesztość Demograficzna Polski 17 (1987), 273; C. Kuklo, Demografia Rzeczypospolitej przedrozbiorowej (Warszawa, 2009), 280-282.

${ }^{124}$ M. Szołtysek, Ludność parafii bujakowskiej w XVIII i XIX wieku. Między ,, unikalnym” systemem formowania się gospodarstw a swoistościa pogranicza, unpublished PhD dissertation (Wrocław, 2003), 124-155; also Kuklo, Demografia Rzeczypospolitej, 356.

${ }^{125}$ Kopczyński, Studia nad rodzina, 108, 171.

${ }^{126}$ Kuklo, Kobieta samotna, 77-83.

${ }^{127}$ C. Kuklo, 'Typology of household in the Polish town of the pre-industrial age', Polish Population Review 10 (1997), 255; Kuklo, Kobieta samotna, 83.

${ }^{128}$ M. Szołtysek, 'Central European household and family systems, and the "Hajnal-Mitterauer" line: the parish of Bujakow (18th-19th centuries)', History of the Family 1 (2007), 19-42.

${ }^{129}$ M. Szołtysek, 'Astride the Hajnal line - household and family in the Upper Silesian parish of Bujakow, 17661803', Polish Population Review 11 (2004), 88-89.

${ }_{130}$ A. Laszuk, Ludność województwa podlaskiego w drugiej połowie XVII wieku (Warszawa, 1999), 120-123, $189-195$

${ }^{131}$ Z. Budzyński, Kresy południowo-wschodnie w drugiej połowie XVIII w. T. 3: Studia z dziejów spotecznych (Przemyśl-Rzeszów, 2008), 163-164, 170.

${ }^{132}$ M. Szołtysek, and D. Biskup, 'Różnorodność czy tożsamość? Chłopskie gospodarstwo domowe na ziemiach Rzeczypospolitej i Śląska pod koniec XVIII wieku', in C. Kuklo ed., Rodzina i gospodarstwo domowe na ziemiach polskich w XV-XX wieku. Struktury demograficzne, spoteczne i gospodarcze (Warszawa, 2008), 363390; Szołtysek, 'Three kinds', 27-28; also M. Szołtysek, 'Rethinking Eastern Europe: household formation patterns in the Polish-Lithuanian Commonwealth and European family systems', Continuity and Change 23 (2008), 389-427; M. Szołtysek, 'Life cycle service and family systems in the rural countryside: a lesson from historical East-Central Europe', Annales de Démographie Historique 1 (2009), 53-94. 
${ }^{133}$ N. Sliž, 'Dasledavanne gistoryi sjam'i: njavykarystanyja magčymasci belaruskaj gistaryjagrafii', Gistaryčny Al'manah 10 (2004) (http://kamunikat.fontel.net/www/czasopisy/almanach/10/07.htm).

${ }^{134}$ Aggregated data for 15 estates with 791 households; see A.I. Višniauskaite, 'Razvitie litovskoj krest'ianskoj sem'I'. Proceedings of the VII International Congress of Anthropological and Ethnological Sciences (Moscow, 1971), 8-12. By transposing the data from 1594-1700 onto Laslett's typology, we get the percentage of simple households estimated at $81 \%$, with only a very slight contribution of multiple-family domestic groups valued at $6.9 \%$.

${ }^{135}$ Višniauskaitè, 'Razvitie litovskoj’, 4.

${ }^{136}$ Višniauskaité, 'Razvitie litovskoj, 7.

${ }^{137}$ Z. Kapyski, and B. Kapyski, 'Belaruskaia veska i iae nasel'nitstva u kantsy XVI-pershai palove XVII st. Vopyt demagrafichnai kharakterystyki', The Belarusian Historical Journal 2 (1993), 43.

${ }^{138}$ V.F. Golubev, Sialianskaie zemlevladanne i zemlekarystannne na Belarusi XVI-XVIII ctct (Minsk, 1992), 88.

${ }^{139}$ V. Nosevich, Tradicionnaja belorusskaja derevnja v evropejskoj perspektive (Minsk, 2004), 81-87.

${ }^{140}$ Nosevich, Tradicionnaja belorusskaja, 157-176.

${ }^{141}$ V. Nosevich, 'The multiple-family household: relic of a patriarchal past or more recent phenomenon?', paper presented at Cambridge Group for the History of Population and Social Structure, August 2007; Nosevich, Tradicionnaja belorusskaja, 176.

${ }^{142}$ Nosevich, 'The multiple-family household'.

${ }^{143}$ R. Tchmelyk, 'Dejaki mirkuvannja pro viniknennja maloi sim`i na ukaini', Narodna tvorcist' ta etnohrafija 3 (1992), 41.

${ }^{144}$ R. Tchmelyk, Mala ukrains'ka seljans'ka simja druhoi polovyny XIX - po`catku XX st. (L'viv, 1999). That tendency to portray "Little Russians" (Ukrainians) as "individualists" in opposition to Russians, and, respectively, to present the societal traits of 'Great Russians' (Russians per se) in collective terms, was pinpointed by Kovalevskij already in 1885 (M. Kovalevskii, 'Obscinnoe zemelelevladenie v Malorossii v XVIII veke', Juridiceskij vestnik 1 (1885), 36-69).

${ }^{145}$ V.V. Tarnovskiy, 'O delimosti semejstv v Malorossii', Trudy Komissii dlja opisannja gubernij Kievskogo učebnogo okruga 2 (1853), 1-15. Based on Tarnovskiy's "field work" observation in one village of Kijowszczyzna (central Ukraine).

${ }^{146}$ Gubrik argued that in the second half of the $16^{\text {th }}$ century the Volhynia multiple-family co-residence was only a rare phenomenon, and that single family households predominated. The picture changed dramatically when moving eastward through the northern Ukraine (A.O. Gurbik, 'Seljans'kij simejnij lad', in V. A. Smolij ed., Istorija ukrains'kogo seljanstva: Narisi v 2-x t., vol. 1 (Kiiv, 2006),152-158). In our opinion, the basic statistics on household structure provided by the author do not fully confirm his interpretive ventures.

${ }_{147}$ J. Goško, Naselennja ukrains'kix Karpat XV-XVIII st. (Zaselennja. Migracii. Pobut) (Kiiv, 1976), 161-164; J. Goško, 'Simja v Karpatach ta Podkarpatti v XVI-XIX st.', Naukowij zbirnik Muzeju ukrainskoj kultury v Swidniku 19 (1994), 234-242.

${ }_{148}$ Goško, Naselennja ukrains'kix Karpat, 138-139, 162-164.

${ }^{149}$ O. Nahodil, 'K problému rozkladu velkorodiny u východoslovenských Ukrajinců', Universitas Carolina / Philosophica 1, 2 (1955), $151 \mathrm{ff}$.

150 A.L. Perkovskij, 'O ljudnosti ukrainskogo dvora i veličine sem'i vo vtoroj polovine XVIII veka (Po materialam Rumjancevskoj opisi i cerkovnoj statistiki)', in R. Pullat Ed., Problemy istoričeskoj demografii SSSR. Sb. statej (Tallin, 1977), 106-107, 111; A.L. Perkovs'kij, 'Evoljucija simi i gospodarstva na Ukraini v XVII - peršij polovini XIX st.', Demografični doslidžennja 4 (1979), 41-44. Perkovskii linked that process with the decline in joint-family farming resulting from demographic growth and in the increasingly unfavorable land/population ratio.

${ }^{151}$ M.G. Krikun, 'Naselennja domogospodarstva u Žitomirs'komu poviti Kiivs'kogo voevodstva 1791 r.', Ukraina moderna 6 (2001), 25 - 46; O. Sakalo, 'Domogospodarstva sil's'kogo naselennja Get'manščini drugoi polovini XVIII st.: dejaki istoriko-demografični aspekti (na prikladi sela Vedmeže Romens'koi sotni Lubens'kogo polku)', Kraeznavstvo 1-4 (2008), 168-174; also Gruber and Szołtysek, 'Stem families, joint families'.

${ }^{152}$ On the concept of symbolic geography, see Bakic-Hayden \& Hayden, 1992.

${ }^{153}$ Kertzer, 'Household history', 163.

${ }^{154}$ Alderson and Sanderson, 'Historic European household', 426; R. L. Rudolph, 'The European Peasant Family and Economy: Central Themes and Issues', Journal of Family History 17, 2 (1992), 122-124.

${ }^{155}$ Conflating household size with household internal composition-and drawing bold conclusions about the latter from an analysis of data based solely on the number of domestics-seems a more general problem which discredits many Ukrainian studies of historical family forms (e.g. Tchmelyk, Mala ukrains'ka, 34, 64-69).

${ }^{156}$ The lion's share of the Eastern European studies of historical families relied on interregional and crosstemporal comparisons of the percentage of households that are simple, extended, or multiple. Such comparisons 
may, however, often be meaningless, as demographic opportunities to form different types of households may differ significantly between different regional populations, as well as between population distanced in time (see S. Ruggles, Prolonged Connections: The Rise of the Extended Family in Nineteenth. Century England and America (Madison, 1987), 142 ff. and S. Ruggles, 'The future of historical demography', Annual Review of Sociology 38 (2012, forthcoming) for a sound methodological argument; also Gruber and Szołtysek, 'Stem families, joint families').

${ }^{157}$ Much seems to signal that the picture of Eastern European peasant family fixed in the minds of Western scholars was significantly affected by a rather unimpressive body of works treating essentially on familial behaviors in the post-enfranchisement era. Indeed, Polish ethnographic knowledge suggests that peasant enfranchisement in the second half of the 19th century might have brought about a marked increase in the number of multi-generational families among the rural classes (Kopczyński, Studia nad rodzina, 108). According to Markowska, a multi-generational family settling in Polish lands was only a temporary phenomenon, typical of the transition from feudalism to capitalism (D. Markowska, Rodzina wiejska na Podlasiu (1864-1964) (Warszawa, 1970), 195). The ephemeral emergence of this type of family arrangement in Polish lands between the years 1880 and 1900 — that is, roughly during the period referred to in Hajnal's nuptiality statistics-perhaps points to the sole historical moment in which it is indeed possible to capture the phenomenon of multi-generational dwelling in one place in the history of the East-Central European family. The conclusions coming from these works, however, cannot be transposed onto earlier periods.

${ }^{158}$ M. Szołtysek, 'Residence patterns and human-ecological setting in historical Eastern Europe: a challenge of compositional (re)analysis', paper presented at the International workshop "Population in the human sciences: concepts, models, evidence" Oxford University, Institute of Human Sciences (United Kingdom), September 2011.

${ }^{159}$ M. Szołtysek and S. Gruber, 'Spatial variation in residence patterns in pre-1900 Germany: comparing aggregate statistics and census microdata', paper presented at the 36th Annual Meeting of the Social Science History Association "Generation to Generation", Boston Park Plaza Hotel and Towers, Boston, MA (USA), November 2011; M. Szołtysek and S. Gruber, 'All in the bosom of the family? Living arrangements of the aged in two Eastern European joint-family societies', ibid.

${ }^{160}$ O. Halecki, The limits and divisions of European history (New York, 1950), 138. 